\title{
Gender Equality in the Governance of the Arctic Region
}

\author{
Eva-Maria Svensson ${ }^{1}$ \\ Department of Law, University of Gothenburg, Sweden
}

\begin{abstract}
Gender equality is a fundamental political and legal obligation for most of the world's states. The public governance of the Arctic, performed by democratic institutions established by the Arctic states, has the obligation to meet the needs of all. This article presents an analysis on whether the structure of the governance meets the needs of all equally. The analysis of the organisation's rhetoric and activities shows what interests and whose which are maintained, as well as those who are not prioritised. Gender equality and other social sustainable considerations are treated as reactive in relation to economic development. Gender equality, as well as equality between different ethnic groups, have not, so far, been prioritised within the public governance of the Arctic despite farreaching obligations for the concerned states.
\end{abstract}

Keywords: Gender equality, public governance, social sustainable development, arctic region, legal obligations

\section{Introduction}

Gender equality is a fundamental political and legal obligation for most of the world's states. The significance of gender equality has been reaffirmed and strengthened through the global review of state obligations to eliminate gender discrimination and through the adoption of the United Nations Sustainable Development Goals in 2015 (Economic and Social Council 2014; United Nations 2015). According to the World Bank "(a) central element of good governance is the responsiveness of policies and public institutions to the needs of all citizens. Policies and institutions must represent the interests of women and men and promote equal access to resources, rights, and voice" (The World Bank 2006). Obligations to promote gender equality and the interests of the indigenous people are obviously interlinked (United Nations 2007). For these reasons, it is relevant to expect public governance by states within the Arctic region to recognise and promote gender equality,

\footnotetext{
${ }^{1}$ Corresponding author. Address: Eva-Maria Svensson, Department of Law, School of Business, Economics and Law, University of Gothenburg, Box 650, SE-405 30 Gothenburg, Sweden. E-mail: eva-maria.svensson@law.gu.se
} 
in order to meet the needs and interests of all citizens and promote equal access to resources, rights and voice.

Government's objectives can be achieved through regulatory policies, administrative and budgetary planning as well as through formal laws, constitutional provisions, and domestic acceptance of international legal obligations grounded in treaties. The international basis for state obligations to promote and attain gender equality is the Convention on the Elimination of All Forms of Discrimination against Women (CEDAW) and the Beijing Declaration and Platform for Action from $1995 .^{2}$

This article sketches the nature and agendas of the regional public governance that have taken responsibility for various aspects of Arctic. It addresses how gender equality is understood (the rhetoric aspect), how it is done (the strategic aspect) and whether gender equality is achieved (the implementation aspect). Not surprisingly, these bodies have formed in response to the growing interest internationally in the Arctic as an area of economic significance due to its increasingly exploitable natural resources. Although some of these bodies have come to be concerned also with the climate, social, and Indigenous dimensions of increased economic and political interest in this part of the world, gender equality issues continue to be marginalised by most of these bodies.

The eight states in the Arctic region represented through various regional bodies are Canada, Denmark (Greenland), Finland, Iceland, Norway, the Russian Federation, Sweden and the United States. Additional states and international organisations are also involved in the governance of the region as observers or permanent participants. As yet, however, none of these regional bodies have taken steps to extend their members' governance obligations to gender equality or Indigenous rights to their own actions in any substantive or binding ways.

The focus in this chapter is on public regional bodies that have been established by the states and governments with territories within the Arctic region. Private governance bodies are of immense importance for the development of the region, but the main issue here is the obligations of the state concerning gender equality, and how these obligations are met within the state-initiated bodies empowered to govern the Arctic region. Farreaching international political and legal commitments lead to the expectation that these bodies, as representatives of the states, are obliged to take comprehensive, appropriate and efficient measures to achieve the democratic goal of gender equality within their scope. This article examines the extent to which these obligations remain largely unfulfilled.

\footnotetext{
${ }^{2}$ The full texts of the Beijing Declaration and the Platform for Action are found in United Nations (1995). See also Lahey (2010, 27-106); Philipps (2006, 143-168).
} 


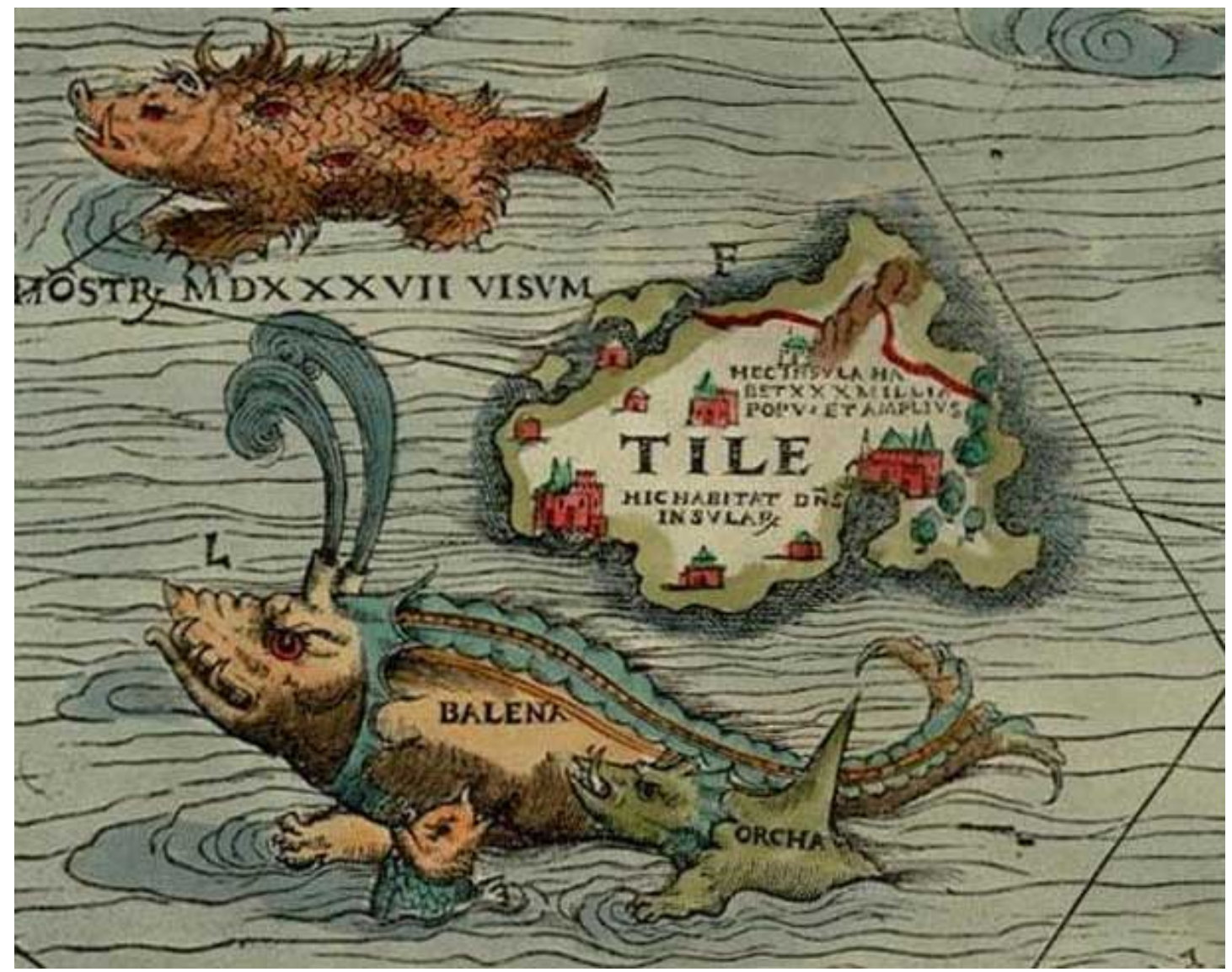

Figure 1. Map of Thule.

Source: https://upload.wikimedia.org/wikipedia/commons/4/44/Thule_carta_marina_Ola us_Magnus.jpg (Accessed 2017-02-08).

In classical European literature and maps such as in Figure 1, the region in the far north, often considered to be an island, was called Thule (with variations in spelling). There are different interpretations of what was meant by Thule; Norway, Scandinavia (sometimes including the Orkney and Shetland Islands), Iceland, Greenland or Saaremaa in the Baltic Sea. ${ }^{3}$

\section{Material and method for the study}

The study of how gender equality is understood and how it is done in the public governance of the Arctic has been carried out by means of a reading

\footnotetext{
${ }^{3}$ The name Thule can be controversial, combined with Ultima (meaning beyond the borders of the known) it is sometimes used today as an ideological concept for ultra nationalist groups.
} 
of the governing bodies' own statements in the webpages and documents reachable from the same pages. The search words gender*, gender (in)equality, woman/women* and man/men* have been used, to find direct statements and/or discussions relevant to gender equality. The search was mainly performed at the beginning of 2014 (February), but there was also a follow-up in 2015 (June) to check what has happened since February 2014. The study has been possible because of the limited number of hits. More detailed information relating closely to the questions mentioned above is given below.

An external source has been used with reference to the question of whether gender equality is achieved. Seven of the Arctic States have ratified the most important legally binding document regarding gender equality, the CEDAW. Every four years, the state parties are expected to report to the CEDAW Committee about the conditions in the country. The Committee comments on the reports, and follows development over time based on previous reports. The comments apply to the situation in the whole state, but some issues are highlighted as especially concerning the conditions in the northern region (the Arctic) and other issues relevant for this region. The comments can, of course, be criticised for not giving the whole picture as they are based on what the states themselves address in their country report, respectively. However, there are additional non-governmental reports which are also read by the Committee, and moreover, the issues raised in the comments do not differ to any degree from other international bench-marking initiatives such as Gender Gap Indexes. The criticism from the CEDAW Committee is used here as a tool with which to scrutinise the public governance bodies of the Arctic. The study was performed in 2015, when the most recent reports were from the years 2006-2009, considered by the committee in 2008 and 2010. Since then the three countries chosen here, have submitted new reports considered by the committee in 2015 and 2016, respectively. Only the comments on the Swedish report have been considered in this article.

Moreover, during the spring of 2012 I contacted the Swedish foreign ministry to ask what Sweden intended to do during its chairmanship of the Arctic Council on gender equality. The background for the question was a statement that gender equality was important for the Swedish chairmanship, but at the same time there was no information about any activities what so ever. This initial contact led to further contact - during the open seminar closely connected to the Ministerial meeting in Kiruna in 2013 and through participation in the gender equality conference in Akureyri, Iceland, in October 2014. Some of the insights gained through this contact are also a part of the study, and could also be seen as part of the method. 


\section{What is "the Arctic"?}

The demarcation of the region denoted to as "the Arctic" remains contested by states with territorial and economic interests in the circumpolar region, and by the various bodies that claim to govern all or part of this area. The specific boundaries identified for the region depend on the purpose for which researchers, states, or organisations define those boundaries. No matter which demarcation is used, however, transnational governance of the region is made up of many overlapping governing bodies.

The Arctic is the northern part of the northern hemisphere, and much of the region consists of the large Arctic Ocean. The simplest demarcation of the Arctic is the Arctic Circle (drawn at roughly $66^{\circ} 34^{\prime}$ north). This geographical definition is shown as a blue line in Figure 2. Alternatively, the region can be defined by reference to the tree line or by locations where average daily temperatures for the warmest month (July) remain below 10 degrees Celsius. The red line in Figure 2 shows this way to define the area. None of these definitions include all eight circumpolar countries that claim segments of the Arctic in territorial terms; the latitudinal definition exclude Iceland, while the tree line and temperature definition includes Iceland but excludes Sweden and Finland. 


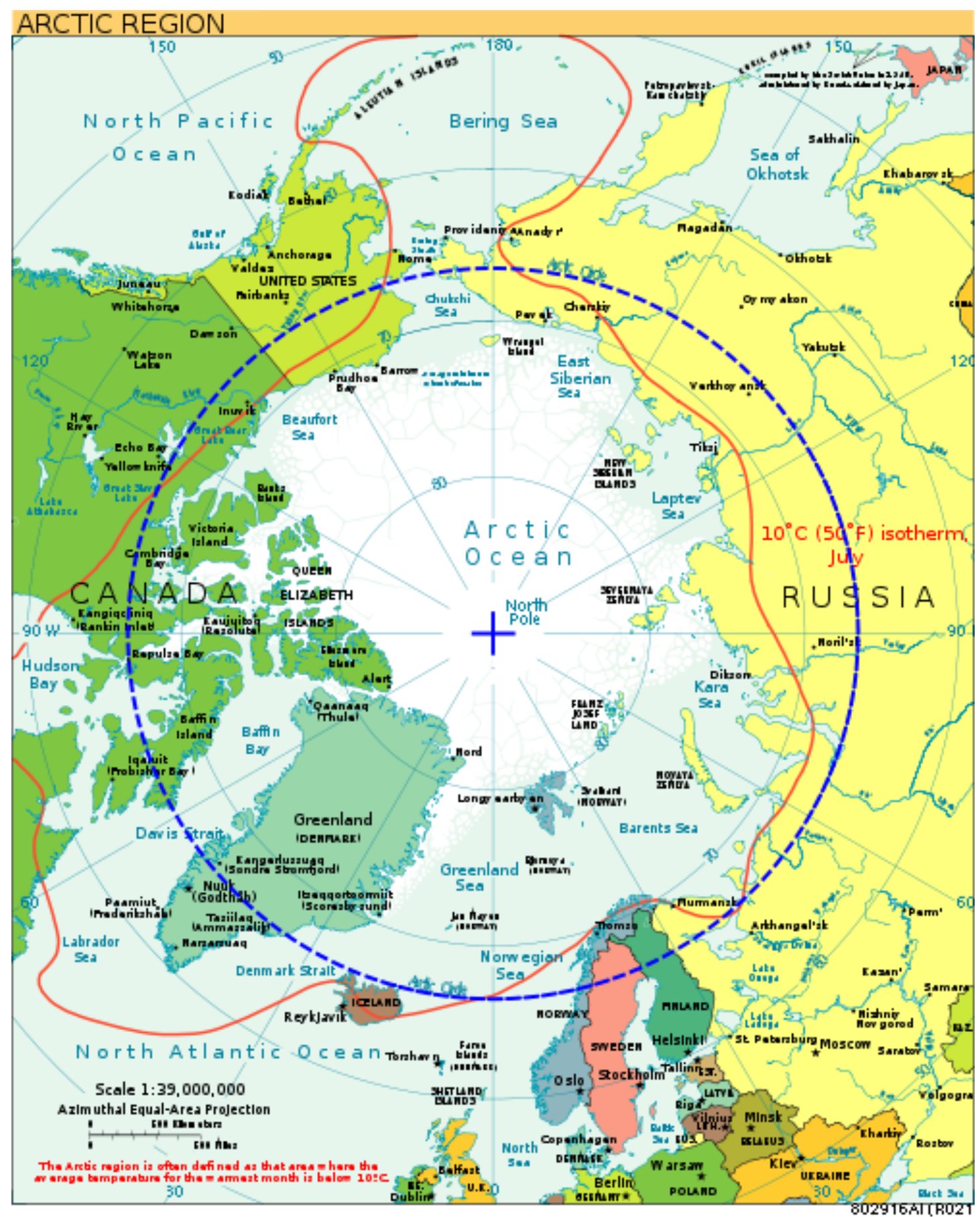

Figure 2. Map of the Arctic.

Source: https://upload.wikimedia.org/wikipedia/commons/3/31/Arctic_circle.svg (Accessed 2017-02-08). 
Administrative definitions of the Arctic are also unique, depending on the purposes for which they are identified. For example, the Arctic Council has created boundary lines on the circumpolar map relevant to its mandates. The various working groups have slightly different demarcations as shown in Figures 3 to 5.

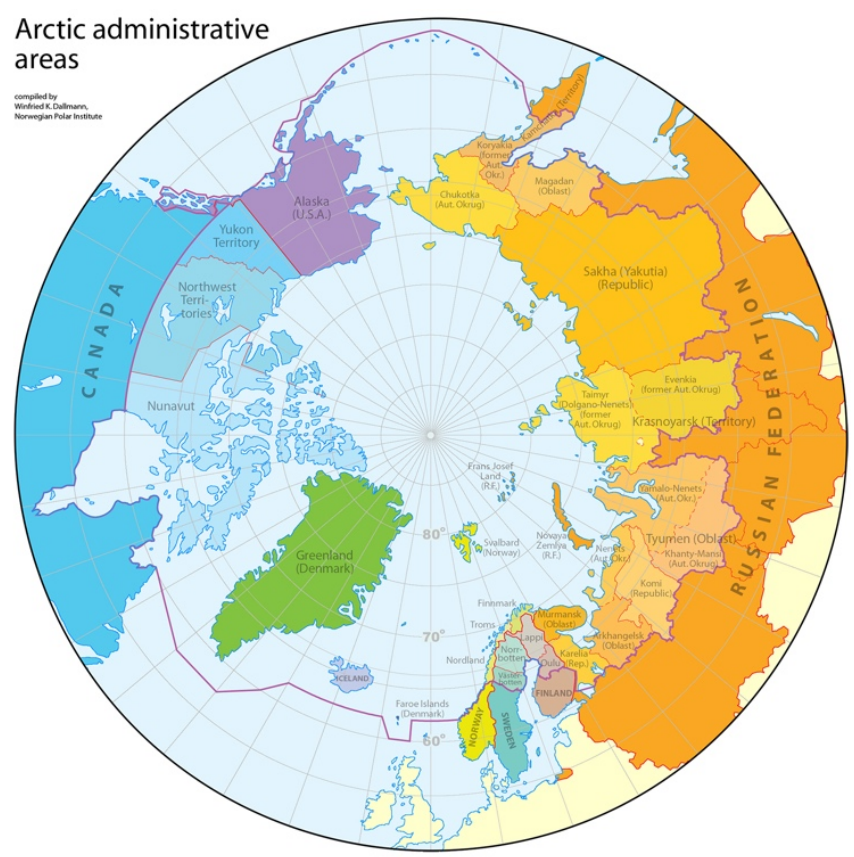

Figure 3. Map of Arctic administrative areas.

Source: Arctic Council Secretariat (Winfried Dallmann), http://www.arctic-

council.org/images/PDF_attachments/Maps/admin_areas.pdf (Accessed 2017-08-10). 


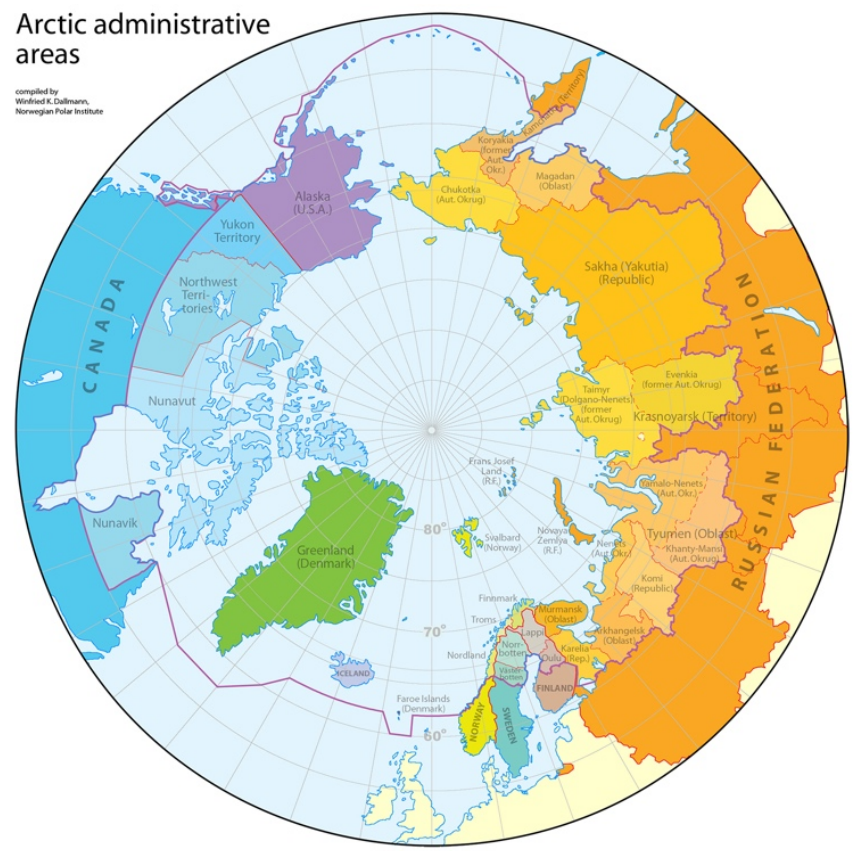

Figure 4. Map of Arctic administrative arenas, including Nunavik.

Source: Arctic Council Secretariat (Winfried Dallmann), http://www.arcticcouncil.org/images/PDF_attachments/Maps/admin_areas_wNunavik.pdf Accessed 201708-10). 


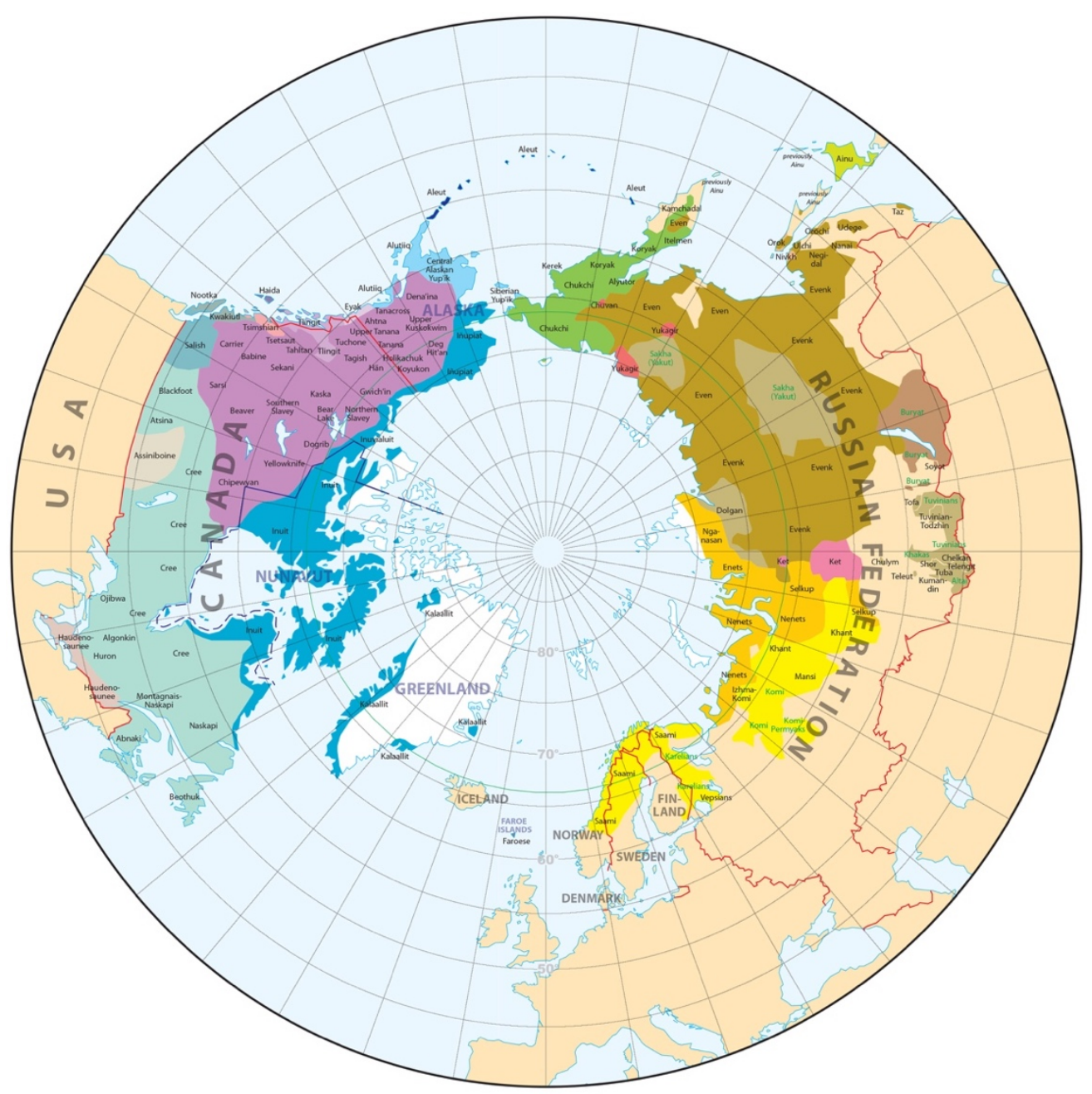

\section{Indigenous peoples of the Arctic countries}

\begin{tabular}{|c|c|c|}
\hline Subdivision according to language families & Eskimo-Aleut family & Notes: \\
\hline Na'Dene family & Inuit group of Eskimo branch & \multirow{2}{*}{$\begin{array}{l}\text { For the USA, only peoples in the State of Alaska are shown. For the Russian } \\
\text { Federation, only peoples of the North, Siberia and Far East are shown. }\end{array}$} \\
\hline Athabaskan branch & Yupik group of Eskimo branch & \\
\hline Eyak branch & Aleut group & \multirow{2}{*}{$\begin{array}{l}\text { Majority populations of independent states are not shown, not even when } \\
\text { they form minorities in adjacent countries (e.g. Finns in Norway). } \\
\text { Areas show colours according to the original languages of the respective } \\
\text { indigenous peoples, even if they do onot speak these languages today. }\end{array}$} \\
\hline Tlingit branch & $\begin{array}{l}\text { Uralic-Yukagiran family } \\
\text { Finno-Uaric branch }\end{array}$ & \\
\hline Penutan family & Samodic branch & \multirow{6}{*}{$\begin{array}{l}\text { Overlapping populations are not shown. The map does not claim to show } \\
\text { exact boundaries between the individual groups. } \\
\text { In the Russian Federation, indigenous peoples have a special status only when } \\
\text { numbering less than } 50,000 \text {. Names of larger indigenous peoples are written } \\
\text { in green. }\end{array}$} \\
\hline Macro-Algonkian family & Yukagiran branch & \\
\hline Algonkian branch & Altaic family & \\
\hline Wakasha branch & Turkic branch & \\
\hline Salish branch & Mongolic branch & \\
\hline Macro-Sioux family & Tunguso-Manchurian branch & \\
\hline Sioux branch & Chukotko-Kamchatkan family & \\
\hline Iroquois branch & Ket (isolated language) & \\
\hline Indo-European family & Nivkh (isolated language) & \\
\hline Germanic branch & Ainu (isolated language) & $\begin{array}{l}\text { compiled by W.K. Dallimann } \\
\text { oNorowegian Polal rnstitute }\end{array}$ \\
\hline
\end{tabular}

Figure 5. Map of indigenous peoples of the Arctic countries.

Source: Arctic Council Secretariat (Winfried Dallmann), http://www.arcticcouncil.org/images/PDF_attachments/Maps/indig_peoples.pdf (Accessed 2017-08-10). 
The Barents Euro-Arctic region encompasses physiographic Arctic parts of Finland, Norway, Russia and Sweden, and also include substantially more southern areas of these countries, see Figure 6.

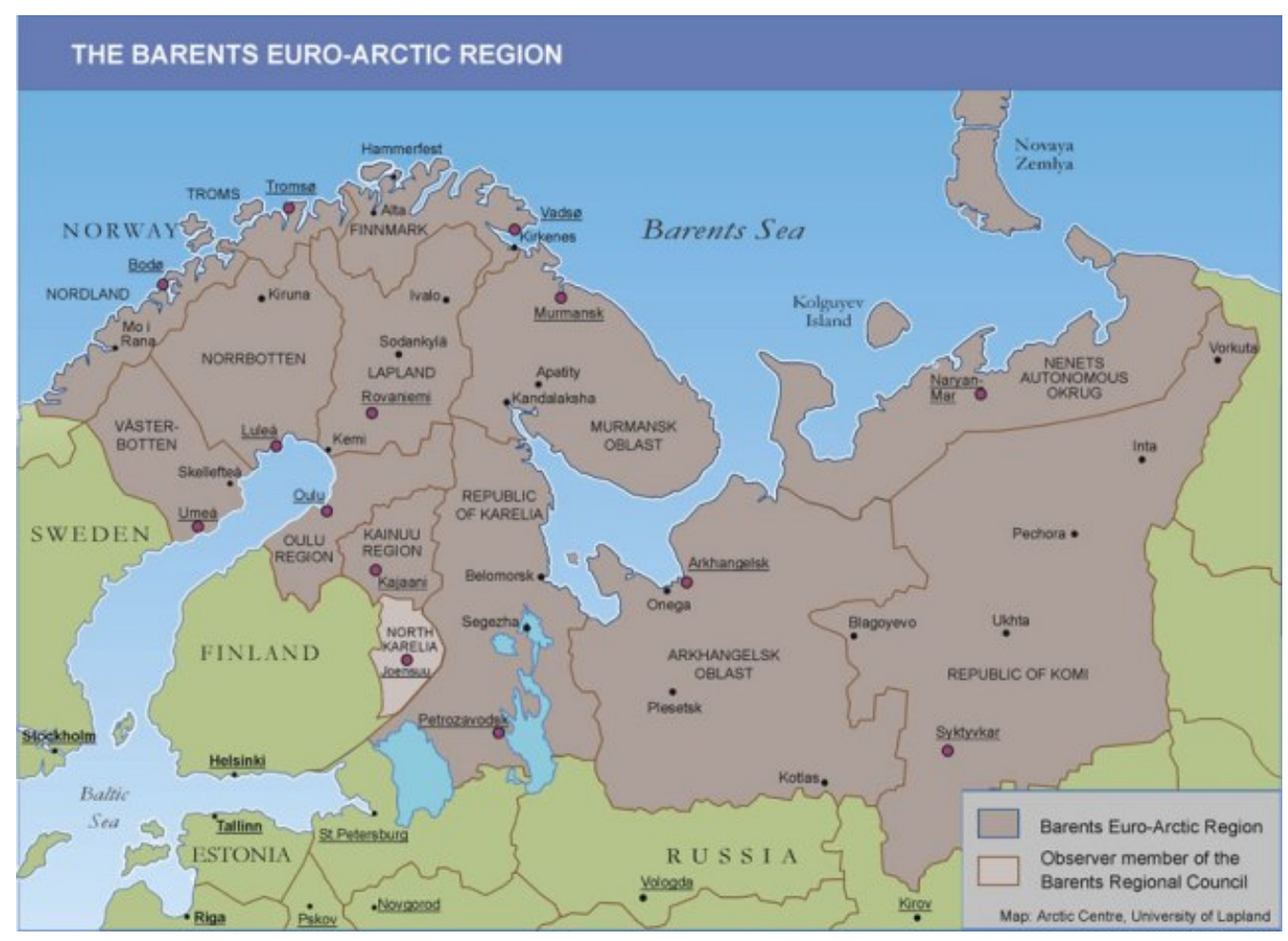

Figure 6. Map of the Barents Euro-Arctic region.

Source: Arctic Centre, University of Lapland, http://www.ramsar.org/sites/default/files/ documents/pictures_2013/news/europe/Norway/bear_map_web.jpg (Accessed 2017-0810).

The European Union Northern dimension policy area is even more expansive, including the whole of Norway, Iceland, Sweden, Finland, Estonia, Latvia, and Lithuania, as well as the Russian Kola Peninsula and northwestern Russian areas, and parts of Belarus, Poland, Denmark, and Germany. This demarcation enables the EU and Russia to address crossborder relations and sea routes through the Baltic Sea and the Arctic Ocean, see Figure 7. 


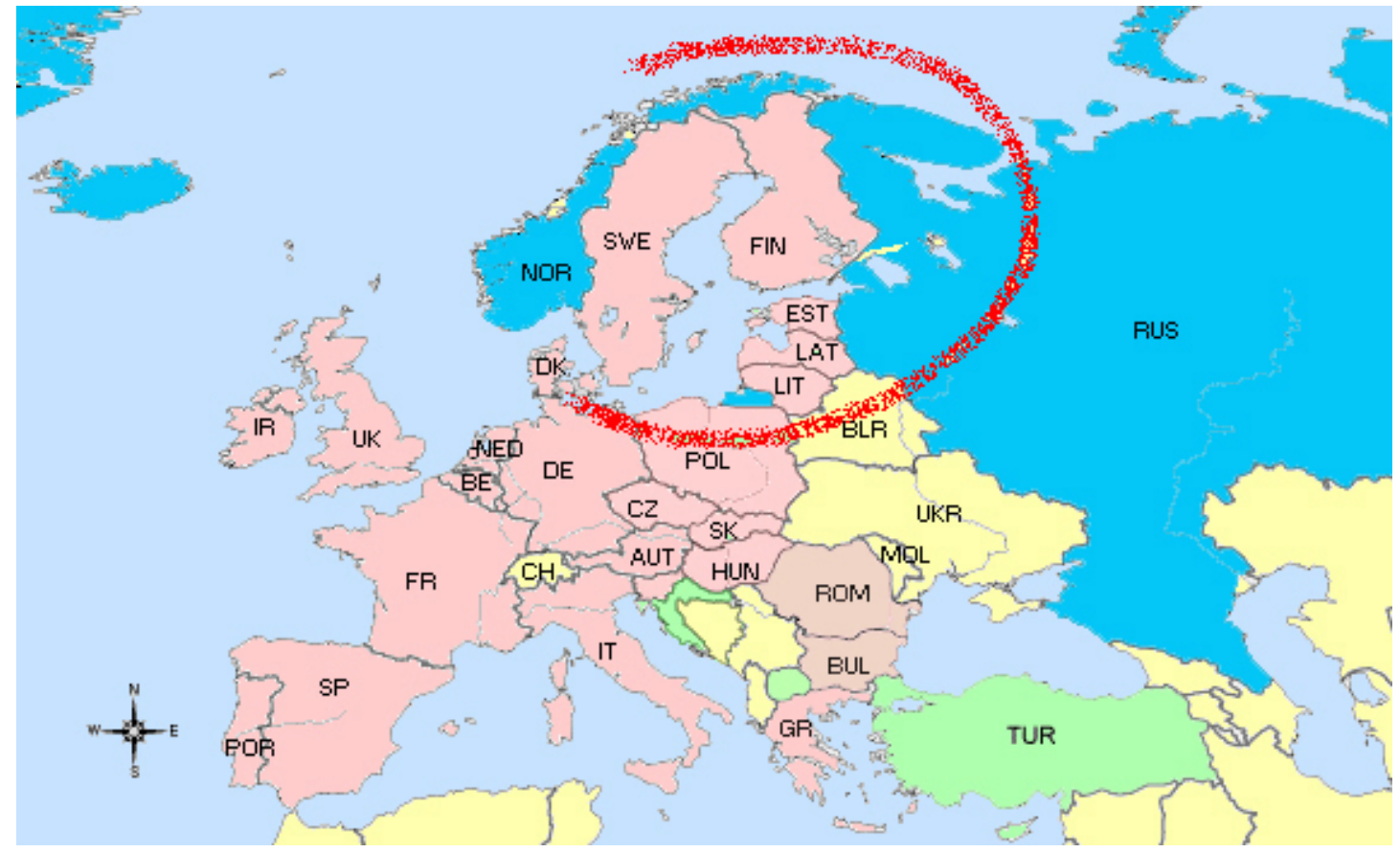

Figure 7. Map of the European Northern dimension policy area.

Source: Northern Dimension Policy Institute, http://eeas.europa.eu/archives/delegations/ russia/images/content/c_dimension01.jpg (Accessed 2017-02-08).

Administrative regions of the Arctic recognised specifically for purposes of Indigenous governance are also demarcated in various ways. No one administrative body considers itself to concern all Indigenous peoples located in or near the Arctic Circle. The most inclusive demarcation is Sápmi, the cultural region traditionally inhabited by the Sami people, see Figure 8. The geographical territory of Sápmi is not precisely defined and has changed over time. Lapland is sometimes understood to be the same as Sápmi. The name Lapland refers to the land inhabited by the Sami people, but the name is used only in Finland and Sweden for the provinces in the north. Sápmi, according to the Samis, is a nation without state or country borders but with a common language, culture and history (Samiskt informationscentrum 2017). The area is comprised of the northern parts of Fennoscandia, and stretches over the four countries of Finland, Norway, Russia and Sweden (Kent 2014). Sápmi is also increasingly recognised as an administrative region, and the Samis participate in public governance of the Arctic. This participation is not as a state, but as a specific group with legitimate interests in the region entitled to membership as permanent participants of the Arctic Council.

The Sami do not constitute the majority population in Sápmi. One estimation is that the total population is 80,000 , with Norway having the 
biggest Sami population (50,000 - 65,000), Russia the smallest $(2,000)$ and the other countries in between (Sweden 20,000 and Finland 8,000).

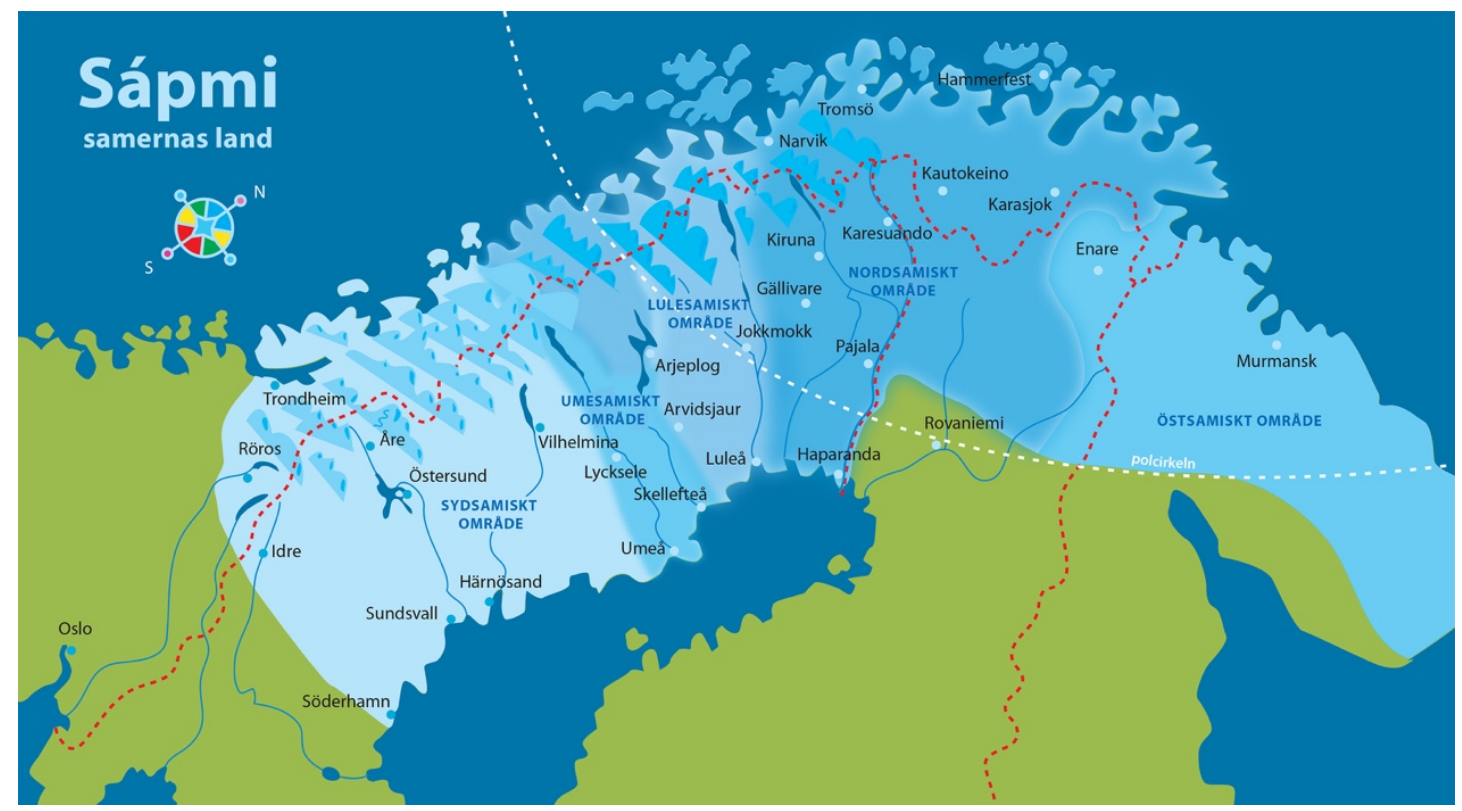

Figure 8. Map of Sápmi.

Source: Samiskt informationscentrum, http://www.samer.se/4314 (Accessed 2017-02-08).

As a consequence of the various demarcations, there are diverging data on the population of the Arctic regions and countries. According to one report (Einarsson 2004, 27) the population was in 2003 approximately 4 million. According to the Arctic Center, also using the circumpolar North as the boundary, the population is a little more than 13 million, of which 10 percent belong to one of 40 indigenous groups (Arctic Centre, 2015). Almost all of these people live as a minority within the borders of contemporary nation states. There is considerable diversity among Indigenous peoples, their legal and constitutional status, and their roles in national or regional governance. Only in Greenland are the Inuit in the majority, constituting 88 percent of the population. In Canada half of the population in the northern regions is indigenous, in Alaska around 20 percent. In the Nordic countries and in north Russia indigenous peoples comprise only 4-5 percent of the population in the region (Arctic Portal 2015). Iceland (if included in the Arctic region) is the only Nordic country without indigenous people.

The population in the Arctic grew rapidly in the 1950s and 1960s due to improved healthcare for indigenous people and a large influx of immigrants resulting from the discovery of vast natural resources located in the region. Recently the population growth has slowed and, between the years 20002010, even declined in many parts of the Arctic (Nordregio 2017a). The net- 
migration pattern among females is stronger than for men, more women than men out-migrate from the north, and the number of females per 100 males in age group 15-64 years is fewer than 100 in strikingly large parts of the Arctic (Nordregio 2017b).

As discussed in both the Arctic Human Development Reports from 2004 and 2015 there is much to say about defining the Arctic; the question of how the area is defined requires further research and consideration (Einarsson 2004, 17; Nymand Larsen and Findahl 2015, 218). As shown, there are several demarcated regions defined from a variety of aspects and interests. Here, the term Arctic is used for the area of land, named as the Arctic region, which is subject to regional governance through various, partly overlapping, bodies, forming the geopolitics of Arctic (Keskitalo 2004; Geopolitics in the High North 2017).

\section{International interest in the Arctic is growing}

The international community, with both public and private stakeholders, is intensifying its interest in the Arctic as an area of economic importance due to its natural, and increasingly accessible, resources. The Arctic is a region with immense amounts of natural resources such as petroleum and minerals, as well as fish and other animal products. These resources are progressively forming the base for expanding economic activities due to the melting of the ice. Moreover, the more the ice melts and the sea opens, the more the Arctic is used through as a transportation route.

It is not only the Arctic states that are interested in the Arctic, states in other parts of the world are also drawn to the natural resources and to access to the region. For example, twelve non-Arctic states have been admitted as observers to the Arctic Council, the six latest in 2013 (Arctic Council Observers 2017). Most of the states are situated far from the Arctic, but the observer status recognises that their interest is significant enough to sit in on meetings. The fear of military interests in the area has been raised, but it is presumed that the main attractions are economic development and trade (New Scientist 2015). The UN Convention on the Law of the Sea (UNCLOS) allows anyone to use shipping lanes on the high sea. Northern passages are very interesting for many states as they shorten distances. An increase in trade will at the same time impact on the ice.

The international interest in the Arctic and its resources is not always consistent with the interest of the people living in the region. The Arctic is subject to climate change and contamination due to human activity in the world and more specifically in the region. Economic activities have impacted on sustainability in several ways; both as a condition for living in the north and as something that has negative effects on the environment. 
Indigenous people are often more affected than others due to their specific connection to the land, inhabited and integrated as it is in their living conditions. Climate change, thus, poses a new threat for indigenous people.

The interest for the Arctic has flourished in the last 30 years and, in the 1990s, several governance bodies were established, as will be elaborated in the section on public governance bodies in the Arctic presented below. When these bodies were established, the CEDAW was already adopted and ratified by most states of the world and, moreover, in the middle of the 1990s the Beijing Platform sharpened the states obligations further. More recently, in 2007, UN adopted the Declaration on the Rights of Indigenous People (UNDRIP). This Declaration recognises the wide range of basic human rights and fundamental freedoms of indigenous peoples such as the right to unrestricted self-determination and inalienable and collective land and resource right. The chronological rise of UN instruments promoting gender equality and human rights for indigenous people coincides with the flourishing governance of the Arctic, a region in which many people belong to various indigenous groups and in which gender equality is not achieved. The governance mechanisms of the Arctic seem to be based rather on an economic rationality than on a gender equal and human rights rationality. I will return to this aspect in the conclusion.

\section{Public governance of the Arctic}

Public governing bodies are obliged to meet the needs and interests of all inhabitants. However, formal national state structures with constitutionally embedded governance responsibilities and powers do not exist in relation to this part of the globe. At the same time, the circumpolar states themselves, non-Arctic populations in those states, other countries, and large investment, shipping, and development corporations have interests in the Arctic that do not always correlate with the interests of Indigenous or non-Indigenous peoples living in the region. And among Arctic residents, gendered social, economic, and political structures create personal and gender hierarchies that further complicate questions of how gender and social equalities generally can be promoted.

\section{What is public regional governance?}

The conventional usage of the concept of governance is for formal and public governance, and is often valued in terms of 'good governance'. Although governments often play a central role in governance, using formal tools such as budgeting, policy and legislation, governance may also include less formal arrangements in meeting the demand for governance in many 
settings. The distinctions between formal and informal as well as between private and public can be used to identify different modes of governance. Governance can also be studied as multilevel vertically and/or horizontally (Söderbaum 2004).

For the purposes of this chapter governance is close to the conventional definition and usage of the term. As in the Arctic Human Development Report from 2015 (Nymand Larsen and Findahl 2015) governance comprises political systems and geopolitics, but the focus here is on the public governance in the political systems, as the main objective for the study is to explore and to analyse how obligations, taken on by and/or imposed on the states (by international players such as the UN and by the states themselves through legislation and policy) involved in the regional public governance of the Arctic, are expressed in the rhetoric of the governance, performed in their strategies and activities by the governing bodies and met in their outcomes (regarding the last, it is restricted to what is expressed by the UN body, the CEDAW Committee). Political systems include the structures, processes, and actions taken by actors involved in public decision-making for a political community. Geopolitics is the term used to describe international relations among political communities.

Starting with this meaning of public governance, regional governance is a process by which people through governing bodies such as states determine and pursue their collective ends, means, and values within a certain region. How the governance is institutionalised is covered by the concept of government, which lays down which bodies are present in constructing the governance of a region. The governmental bodies can be both public and private. If established by the states or given legal recognition, regional bodies in this article are defined as public. If, for instance, an NGO is legally recognised it is in this sense a public body. The normal public body, however, is an organisation established by several national states for purposes of co-operation in specific issues. Governance can also be private or a combination of public and private. In this article, the bodies established by the states, part of public governance, are of special interest, because when it is a matter of gender equality policy obligations and to considering the interests of indigenous people, these bodies are obliged to follow the ambitions of the states, which established them. These states can, of course, have different levels of ambition and different legal instruments to follow. However, with regard to legal obligations concerning gender equality and indigenous rights there are several internationally binding instruments (at least there are if the states have ratified them).

The Arctic Governance Project speaks of governance in the Arctic context as "a social function centered on steering human societies away from bad outcomes (...) and toward good outcomes (...) (The Arctic Governance 
Project 2015). By definition, however, Arctic governance can only be organised by state bodies and non-state bodies with interests and jurisdiction in parts of the region. Arctic governance, if established by states, is obliged to follow the same ambitions and values in regional governance as in the rest of the individual states' governance structures. One of these obligations is to promote gender equality and to take all appropriate measures to eliminate discrimination on the basis of sex, and the other is to respect and protect the rights of Indigenous peoples living within their borders or treaty areas. Thus multiple dimensions of public governance call for realisation consistent with each state's constitution and international obligations, and realisation of gender equality rights as well as the rights of Indigenous peoples (Nymand Larsen and Findahl 2015, 194).

The public governance in this chapter, comprises certain bodies established by the Arctic state governments to secure certain interests within a specific geographically demarcated area i.e. the Arctic (cf. the various demarcations shown in section 2). The Arctic encompasses human settlements with particular physical, social, cultural, economic, political, and functional characteristics. The governance of this region is organised in state bodies and non-state bodies with interests and jurisdiction in (parts of) the region. The governance, if established by states, is obliged to follow the same ambitions and values in the regional governance as in the rest of the state governance. One of these obligations is to promote gender equality and to take all appropriate measures to eliminate discrimination on the basis of sex. The bodies are often a combination of representatives from the states concerned and those from indigenous people's organisations (NGO) living in the region.

The governance of the Arctic region was established for a certain purpose. In short, the governance of the Arctic region was established as a result of conflicting economic interests in the natural resources of the region. Several states claim access to these resources. The governance also has additional purposes, which are to balance these interests with the interests of the people living in the region, i.e. the indigenous people, and with environmental interests.

\section{Public governance bodies in the Arctic region}

There are several public bodies for governance of the Arctic region on different levels. The broadest level of governance is the pan-Arctic level, with the Arctic Council and the Conference of Arctic Parliamentarians as forums for interstate co-operation. There are also several indigenous Arctic Organisations, and a sub-national collaborative body, the Northern Forum, gathering subnational or regional units from both Arctic states and non- 
Arctic states. The EU has also evolved an Arctic policy (European Commission 2016) and is a partner in The Northern Dimension.

Examples of regional collaborations between countries or counties situated in the region are the Barents Euro-Arctic Council, the Barents Regional Council, the Council of the Baltic Sea States, the West Nordic Council, The Nordic Council including the Nordic Council of Ministers. The last two are bodies concerned with co-operation between the Nordic countries in a wide range of areas including research, the environment, welfare and culture. All the Nordic countries are partly situated and have interests in the Arctic region.

There is a co-operation council, the Sami Parliamentary Conference and Council, for the Sami parliaments in Norway, Finland and Sweden. Other indigenous regional collaborations are Gwich'in Council International and the Arctic Athabaskan Council.

Apart from the public bodies there are several co-operation enterprises between companies, such as BarentsNova (Barentsnova 2015), an innovation co-operation between Norway and Russia, and SIVA IM (Siva 2015), a Norwegian state-owned company for promoting innovation and business abroad. The key markets for SIVA IM are the Baltic states, northwest Russia and the Balkans. The Arctic Governance Project, is also a nonpublic intitiative, gathering preeminent researchers, indigenous leaders, and members of the policy community to frame the critical issues of governance in the Arctic and devise innovative responses for a sustainable future (The Arctic Governance Project 2015). There are also some nongovernmental organisations, one example from the Scandinavian countries being the Sámi Council (Saami Council 2017). The Council has Sámi member organisations in Finland, Russia, Norway and Sweden. It was established in 1956 and its primary aim is the promotion of Sámi rights and interests in the four countries. The objective can be achieved through agreements between the states and the Sámi Parliaments in each country.

Below, the most important public bodies and their purposes are presented briefly. Co-operation seems to be key for purpose. Each body has co-operation as its own aim, however, the bodies also see co-operation between themselves as important. All Northern regional councils, with their different memberships, identify needs for development and co-operation in their respective areas and support project implementation in different ways. What is also notable is that topic buzzwords such as sustainability and human development are frequently used. 


\section{The Arctic Council ${ }^{4}$}

The Ottawa Declaration of 1996 (Declaration on the Establishment of the Arctic Council, art 1) formally established the Arctic Council (AC) as a highlevel intergovernmental forum to provide a means for promoting cooperation, coordination and interaction among the Arctic States, with the involvement of the Arctic Indigenous communities and other Arctic inhabitants on common Arctic issues, in particular issues of sustainable development and environmental protection in the Arctic. The aim was also to oversee and coordinate certain programs for conservation and protection of for instance flora, fauna and marine environments, and to adopt terms of reference for as well as oversee and coordinate a sustainable development program. Finally, the Arctic Council was to disseminate information, encourage education and promote interest in Arctic-related issues. The Declaration identifies who can be a member, a permanent participant and an observer. Decisions are to be by consensus of the Members. The permanent participants play no part of the decisions having only the right to participate and to be consulted.

The Arctic Council comprises eight Arctic states, Canada, Denmark, Finland, Iceland, Norway, Russia, Sweden and the USA. Six international organisations representing Arctic Indigenous Peoples have permanent participant status. The organisations are the Arctic Athabaskan Council (AAC), Aleut International Organisation (GGI), Gwich'in Council International (GGI), Inuit Circumpolar Council (ICC), Russian Arctic Indigenous People of the North (RAIPON) and the Saami Council (SC).

The geographic area covered by the Arctic Council is the Arctic region. In this region the population is, according to Arctic Council, 4 million (cf. above) of which approximately 10 percent is indigenous.

The Arctic Council provides a valuable platform for discussions on all issues of relevance to the Arctic and the people who live there. The focus is on environmental protection, climate change, arctic and circumpolar biodiversity, marine and shipping activity in the oceans and of the Arctic peoples, and the work around these topics take place in the various working groups. For the Arctic peoples, the focus is on health and well-being as well as the cultural heritage and the preservation of language.

The common objectives for the chairmanship of Norway, Denmark, and Sweden 2006-2013 were concerned with climate change, environmental protection, circumpolar observation and the monitoring of change in the Arctic, integrated management of resources, indigenous people and local living conditions. The prioritised objective for Canada's chairmanship the following period of 2013-2015 was to promote economic development, even if the Declaration of the Arctic Council from 2013 explicitly highlighted the

${ }^{4}$ Arctic Council (2015). 
improvement of both economic and social conditions. Business is given a special role in the development of the Arctic and the Arctic Council intends to increase the co-operation and interaction with the business community in order to advance sustainable development in the Arctic (MM08-15 May 2013-Kiruna, Sweden, Kiruna Declaration).

Additionally, there is the Conference of Arctic Parliamentarians (CPAR) and the Standing Committee responsible for work between conferences (Conference of parliamentarians of the Arctic region 2015) which started in 1993 as a forum for legislative branches originally with one of its main priorities being to support the establishment of the Arctic Council. Since then the Standing Committee has worked actively to promote the work of the Council and participates in the meetings of the Arctic Council as an observer. Today the Committee is engaged in issues as shipping possibilities, education and research, human development and climate change.

\section{The Barents Euro-Arctic Council (BEAC) and the Barents Regional Council $(B R C)^{5}$}

The Barents Euro-Arctic Council (BEAC) and the Barents Regional Council (BRC) were established by the Kirkenes Declaration in 1993 to promote cooperation on governmental and regional level. Denmark, Finland, Iceland, Norway, Russia, Sweden and the European Commission are members of the intergovernmental BEAC. The chair rotates between Finland, Norway, Russia and Sweden. The interregional BRC unites 13 member counties and a representative of the indigenous peoples in the northernmost parts of Finland, Norway, Sweden and northwest Russia, i.e. the Sami, the Nenets and the Veps. The indigenous People play an advisory role in relation to both Councils. The International Barents Secretariat is situated in Kirkenes, Norway.

The objectives for BEAC and BRC are to support and promote cooperation and development in the Barents Region, with sustainable development as the overall objective. There are several working groups focusing on economic co-operation, the environment, transport and logistics and rescue co-operation and energy, and also on indigenous people, health, education, culture, tourism and youth and research.

The underlying premise for the establishment of the co-operation is that close co-operation secures long-term political stability and reduces possible tensions, based on the experiences of a region that was the scene of military confrontation during the Cold War.

\footnotetext{
${ }^{5}$ Barents Euro-Arctic Council (2015).
} 


\section{The Northern Dimension ${ }^{6}$}

The Northern Dimension (ND) is a joint policy between the European Union, Russian Federation, Norway and Iceland. It was initiated in 1999, renewed in 2006, and aims to provide a framework for promoting dialogue and concrete co-operation, strengthening stability, wellbeing and increased economic co-operation, and promoting economic integration, competitiveness and sustainable development in Northern Europe.

In addition to the four ND partners, the regional councils the $\mathrm{AC}$, the BEAC together with the Council of the Baltic Sea States and the Nordic Council of Ministers, financial institutions and some other partners also participate. Several partnerships are also connected to ND, including the ND Environmental partnership and ND Partnership in Public Health and Social Wellbeing.

The renewed ND policy from 2006 is expressed in two documents, the ND Political Declaration and ND Policy Framework Document. The Northern dimension is an EU initiative regarding the cross-border and external policies covering the Nordic countries, Baltic States and Russia. The Northern Dimension addresses the specific challenges and opportunities arising in those regions and aims to strengthen dialogue and co-operation between the EU and its member states, the northern countries associated with the EU under the European Economic Area, Norway and Iceland, and Russia. The Northern Dimension is implemented within the framework of the Partnership and Co-operation Agreement with Russia. A particular emphasis is placed on subsidiarity, and on ensuring the active participation of all stakeholders in the North, including regional organisations, local and regional authorities, the academic and business communities, and civil society. Several key priority themes for dialogue and co-operation under the Northern Dimension have been identified, including economy, business and infrastructure, human resources, education, culture, scientific research and health, the environment, nuclear safety, and natural resources, cross-border co-operation and regional development and justice and home affairs.

The Northern Dimension is intended to promote security and stability in the region, as well as help build a safe, clean and accessible environment for all people in the north. It aims to address the special challenges of regional development in northern Europe. These include cold climatic conditions, long distances, and wide disparities in standards of living, environmental challenges including problems with nuclear waste and wastewater management, and insufficient transport and border-crossing facilities. The Northern Dimension is also intended to take advantage of the

${ }^{6}$ Northern Dimension (2015). 
rich potential of the region, for example in terms of natural resources, economic dynamism, and a rich cultural heritage.

A new dimension to this complex relationship is emerging with the melting of the Arctic ice as a result of climate change. Many resources have become newly accessible and this could lead to a power struggle.

The Northern Dimension also has the objectives of addressing the challenges arising from uneven regional development, and helping avoid the emergence of new dividing lines in Europe following EU enlargement. The importance of the Northern Dimension has increased considerably with the enlargement of the Union on 1 May 2004 to include Estonia, Latvia, Lithuania and Poland: eight EU Member States (Denmark, Germany, Poland, Lithuania, Latvia, Estonia, Finland and Sweden) now surround the Baltic Sea, and the EU's shared border with Russia has lengthened significantly.

\section{The Council of the Baltic Sea States ${ }^{7}$}

The Council of the Baltic Sea States (CBSS) is a general political forum for regional inter-governmental co-operation. Its long-term priorities in all its activities are, according to the Riga Declaration and the vision for the region set out in the Vilnius Declaration, regional identity, a sustainable and prosperous region and a safe and secure region. There are objectives mirroring these priorities and a variety of strategic activities within these priorities, such as co-operation concerning transportation, sustainable development, social exclusion, criminal exploitation and human trafficking and children's rights. ${ }^{8}$

The CBSS was established in 1992 by the region's Foreign Ministers in Copenhagen in response to the geopolitical changes that took place in the Baltic Sea region with the ending of the Cold War. Eleven states of the Baltic Sea Region are Members of the Council: Denmark, Estonia, Finland, Germany, Iceland, Latvia, Lithuania, Norway, Poland, Russia, and Sweden. The European Commission is also represented.

The role of the Council is to serve as a forum for guidance and general coordination among the participating states. The foreign minister of the presiding country is responsible for coordinating the Council's activities and is assisted in this work by the Committee of Senior Officials (CSO). The Council does not have a general budget or project fund. Members are responsible for funding common activities and/or for seeking and coordinating financing from other sources. Since 1998, the CBSS Member

\footnotetext{
${ }^{7}$ The Council of the Baltic Sea States (2015).

${ }^{8}$ The Council of the Baltic Sea States, Priorities (2015).
} 
States have jointly financed the Permanent International Secretariat of the CBSS.

\section{Nordic Council of Ministers and the Nordic Council ${ }^{9}$}

The Nordic Council (NC) is the official inter-parliamentary body in the Nordic region, encompassing the Nordic countries of Denmark, Finland, Iceland, Norway, Sweden, the Faroe Islands, Greenland and Åland. The cooperation occurs in a wide range of areas such as research, the environment, welfare and culture. One of the themes for co-operation is the Nordic region in the Arctic.

The Nordic Council was formed in 1952 and a permanent treaty on Nordic co-operation, the Helsinki Treaty, was ratified in Helsinki in 1962. The cooperation covers a wide range of areas. It is built on common values and a willingness to achieve results that contribute to dynamic development and increase Nordic competencies and competitiveness. Several councils, under the generic name The Nordic Council of Ministers (NCM) founded in 1971, are responsible for specific areas, one of them being the Council of Ministers for Gender Equality MR-JÄM established in 1980. The present co-operation programme runs from 2015-2018.

The Nordic welfare model is one of the areas in which long-term trends are shown by indicators of sustainable development (Norden, Sustainable Development 2015). The Nordic welfare model is defined as being based on the shared ideal of equality, social solidarity and social security for all (Nordic Welfare 2015). The other areas are viable ecosystems, changing climate, sustainable use of the earth's resources, and education, research and innovation.

\section{The European Union}

Apart from its involvement in The Northern Dimension (Northern Dimension EU 2015) the EU also is engaged in an Arctic Policy for the EU, the most recent launched in 2016 (European Commission 2017). The Arctic is an area of growing strategic importance, and the EU has an important role to play in supporting the successful Arctic co-operation and in helping to meet the challenges that confront the region. The policy is based on three main policy objectives, protecting and preserving the Arctic in collaboration with its population, promoting the sustainable use of resources and international co-operation (EU Arctic Policy 2015).

In 2010, The EU Arctic Forum started as a cross-sector and cross-party platform in the European Parliament. It soon became the driving force

\footnotetext{
${ }^{9}$ Norden (2015).
} 
behind the European Parliament's "Report on a Sustainable EU Policy for the High North". The Forum is said to be "a meeting point for discussions about Arctic issues in Brussels within a broader European context involving not only core EU institutions such as the European Parliament, the European Commission, the European External Action Service, regions and politicians, but also prominent actors, institutes, companies and networks of science and business both from within and outside the Arctic region" (Arctic Forum Foundation 2015). Among the partners, participants and friends are oil companies.

The EU's Arctic policy was the topic for a hearing in Rovaniemi in February 2013, and in the press release from this hearing it was stated that the Arctic attracts global players in a number of policy areas such as energy, transport and the environment (On an Arctic Policy for the EU 2015).

\section{The Sámi Council and Saami Parliamentary Council (SPR) $)^{10}$}

The Saami Council was established in 1956 by Sami member organisations in Finland, Russia, Norway, and Swede. Its primary aim is the promotion of Sami rights and interests in the four countries. This is done by reaching agreements between the four states and the Sami Parliaments in each country, respectively. The Sami Parliaments in Finland, Norway and Sweden (established in Norway 1989, Sweden 1993, Finland 1973) cooperate in a cross-border democratic collaboration organisation called the Sámi Parliamentary Council (Samiskt parlamentariskt råd, SPR). It was established in 2000 with the Norwegian and Finnish Sami parliaments as members, and the Swedish Sami Parliament joined in 2002. The main objectives of the organisation are to strengthen the cross-boundary collaboration between the Sámi people and to speak for all Sámi in an international context, especially in relation to other indigenous groups. Prioritised areas are Sámi research, Sámi language infrastructure and development, and youth issues.

The Council has been active in promoting the 2007 adoption of The Declaration on the Rights of Indigenous Peoples in the United Nations, as well as the Nordic Sami Convention. The Council also represents the Sámi people in the EU, and has been engaged in various Arctic collaborations. However, the Council is not involved in the Arctic Council, where the Sami Council, a nongovernmental organisation, is a permanent participant.

\footnotetext{
${ }^{10}$ Saami Council (2017).
} 


\section{Obligations to strive for gender equality and to eliminate discrimination against women}

Gender equality is a value codified in political and legal obligations throughout the world. One of the most important international legal documents is The Convention on the Elimination of All Forms of Discrimination against Women (CEDAW). All the states participating in the regional governance bodies of the Arctic, apart from the USA have ratified this document with the objective of eliminating discrimination against women and gaining full equality between men and women. Countries that have ratified or acceded to the Convention are legally bound to put its provisions into practice. Article 2 of the Convention condemns discrimination against women in all its forms and signatories agree to pursue, actively, by all appropriate means and without delay, policies capable of eliminating discrimination against women. Legislation is an important part of the eliminating process. Member states are obliged to take active measures to eliminate discrimination. That is; the obligation goes far beyond recognising equal formal rights, the states are obliged to take all appropriate measures, including legislation, to ensure the full development and advancement of women, for the purpose of guaranteeing them the exercise and enjoyment of human rights and fundamental freedoms on a basis of equality with men in all fields, in particular in the political, social, economic and cultural fields (CEDAW Art. 3).

State parties are committed to the submission of national reports, at least every four years, on measures they have taken to comply with their treaty obligations. The Committee is empowered by the Convention to make general recommendations directed to the state parties. The recommendations to the state parties participating in the governance of the Arctic will be discussed below in relation to the section on the "doing" of gender equality.

CEDAW state parties can also be bound by regional documents, such as the European Convention on Human Rights (ECHR), which is binding on all the European states. The ECHR has a general prohibition on discrimination. While it does not explicitly impose obligations to take active measures to eliminate sex discrimination, it does require that the enjoyment of any right set forth by law shall be secured without discrimination based on specific grounds that include sex. EU Member States are also bound by the Charter of Fundamental Rights of the European Union. Article 21 of the Charter prohibits discrimination on the basis of sex, and Article 23 obligates states to ensure the enactment of measures to achieve gender equality. The Treaty on the Functioning of the European Union (TFEU) ${ }^{11}$ and the Treaty on

${ }^{11}$ TFEU states that in all its activities the Union shall aim to eliminate inequalities and promote equality (Art 8, cf. Art 153, 157). 
European Union (TEU) ${ }^{12}$ also contain the non-discrimination principle and demands for active measures.

International Conventions and Treaties bind the state parties not only legally but also politically. However, neither the non-discrimination principle nor the obligations to maintain active measures are very clear and may be difficult to interpret. This is particularly true regarding the active measures.

\section{The rhetoric, practice and outcome of gender equality in the public governance of the Arctic region}

Gender equality and non-discrimination could be expected to be axiomatic in society, due to the emphasis put on these principles all over the world. The reality however, is that this is not the case. Feminist scholars have used the distinction between rhetoric and practice, political and legal goals and social reality, to scrutinise and point out the gap between those. What is said to be a political goal, a legal principle and a behavioural norm, is not the same as what is put into practice. The difference between rhetoric and practice when it comes to gender equality in the governance of the Arctic will be discussed further.

Taking gender equality as a political and legal commitment as the startingpoint, the way gender equality is spoken of (rhetoric) by the governance bodies, the way gender equality is put into concrete activities (practice), and some examples of the critique raised by the CEDAW Committee directed to three of the CEDAW member states in the Arctic region (outcome), will be discussed here. Because of the limited focus on gender equality it seems to be possible to give a comprehensive presentation of all gender equality measures of the region, but it could be that I have missed some minor measure.

Gender equality and indigenous issues are interrelated within the governance of the Arctic, especially with regard to (indigenous) women. Therefore, any discussion on how gender equality is spoken of and put into practice must also include discussion of how indigenous issues are talked about and put into practice.

\section{The rhetoric of gender equality in the governance of the Arctic}

The public bodies governing the Arctic are obliged to follow the political and legal commitments mentioned above. How do the government bodies

\footnotetext{
${ }^{12}$ TEU states that the Union shall combat discrimination and promote equality (Art 2 and 3).
} 
express these commitments? How are the commitments understood? How is gender equality talked about?

As already mentioned, the material used to answer these questions includes webpages and various documents adopted by the bodies. There is special focus on the Arctic Council as the main governance body for the Arctic region. The results from both searches, February 2014 and June 2015, will be presented. When figures are used the first refer to 2014 and the second to 2015.

\section{Arctic Council}

On the homepage of the intergovernmental forum The Arctic Council the word gender had 9 hits in 2014 and 11 hits in 2015. The hits refer to three activities, one in 2014 (see below) and one statement on gender. The member state Sweden explicitly stated, during its chairmanship (early spring 2013) that, regarding indigenous people, it "highlights the human dimension and the gender perspective in the Arctic Council" (Sweden's strategy for the Arctic region 2011). There is no further explanation of what this means.

The eight members of the Arctic Council have adopted their own national strategies for the Arctic region in recent years; so too has the EU. The strategies have many similarities, but the prioritisations seem to be somewhat different.

The reasons for a strategy for the Arctic, expressed in the Swedish strategy, are said to be several. Three basic goals touching on Indigenous peoples and gender issues have been identified (Nord 2016a, 61 and 65). The first thing that is mentioned is climate change. Climate change affects the Arctic region in a dramatic way, which in turn has a gradual impact on the living conditions of the indigenous populations living there. Their traditional industries and cultural practices are threatened by the changes. Even more disturbing is the effect on the ice cover. An increase in the melting of the ice opens the way for more sea transport in the area, and for greater access to the natural resources. Activity in the region is becoming more intense.

Gender is mentioned within two frameworks in the Swedish strategy. The first is divided in two general statements, the first of which is a statement of common values within the Nordic countries. One of the values is the promotion of gender equality (Sweden's strategy for the Arctic region 2011, 15). The other general statement is that Sweden will work to bring the human dimension and the gender perspective to the fore in Arctic-related co-operation bodies (Sweden's strategy for the Arctic region 2011, 6). When Arctic natural resources are exploited there must be measures to counteract 
the negative health and social impacts of climate change and pollutants. The right of indigenous people to maintain and develop their identity, culture, knowledge transfer and traditional trades must also be upheld.

The second framework within the Swedish strategy in which gender equality is mentioned is in relation to specific measures to increase the participation of Sámi women in political processes. It is said that the Sámi Parliament has been working actively on the issue. The Sámi Parliament has also begun an exchange of experience with Finland, Norway and Russia regarding gender equality, men's violence against women, sexual harassment and abuse (Sweden's strategy for the Arctic region 2011, 41 and 45). Gender equality in the Arctic region is done through measures directed to the Sámi population by the Swedish Government.

The specific group 'women" is mentioned in relation to mercury pollution in the Arctic. Human populations are adversely affected by such pollution because traditional diets often include species of marine mammals and fish that can contain high levels of mercury. Pregnant women, mothers, and children are especially sensitive. 'Men' are not specifically mentioned at all, as far as I can see.

The human dimension, one of the three top priorities in the strategy, is in my view exposed in this setting as being a reaction to the other two top priorities, especially the first one, climate and the environment, but also to economic development. Climate change, an effect of the way we live and political and economic prioritisations, and the economic development seem to be things that happen without human actors. The human dimension is affected by an unquestioned development, it seems and, moreover, the humans in this context are mostly understood to be the indigenous populations in the region. This says two things, no one is responsible for the development and indigenous people are constructed as the others. Activities and prioritisations by non-indigenous populations affect the indigenous population, but the activities and prioritisations by the nonindigenous population are not questioned.

The Arctic Council published the Arctic Human Development Report (AHDR I) during the Icelandic chairmanship in 2004 in collaboration with other bodies, such as the United Nations Development Program, in order to initiate the process of developing a knowledge base for the Arctic Council's Sustainable Development Programme (Einarsson 2004). The report has a broad scope. "Gender issues" are considered in a special chapter (Einarsson 2004, chapter 11) which addresses several critical issues but does not provide an overall assessment of gender issues in the Arctic.

To begin with it highlights different notions of feminism and also the variety within specific communities. Western feminism cannot be placed in opposition to a non-western or an indigenous feminism, and western, non- 
western or indigenous feminism are also not coherent. There are variations between different groups but also within the same group.

The relation between feminism and gender equality is not explicitly discussed but the presumption seems to be made that gender equality and western feminism (i.e. liberal feminism) are synonymous. Even though "defining power relationships" is mentioned without signifying any specific power relationship, it seems to be understood that gender equality is contrary to traditional gender roles, or even to the new ways of organising indigenous couples' lives, with a man at home and a women in paid work. I would like to emphasise, that gender equality, according to political and legal perceptions in e.g. CEDAW and in a Swedish context, is more about equal value, rights, duties and power in both private and public life, rather than about all doing the same thing. When independence is emphasised with regard to gender equality, it is in the meaning that independence may protect individuals from exploitation, abuse and discrimination. It must not mean that people are not free to choose to be mutually independent of each other. Gender equality as a legal principle can be understood as protecting individuals from negative dependence (as when somebody is not able to leave if he/she wants to) but encouraging positive dependence (to choose to live in relations based on free will and not coercion). Putting gender equality as a western concept with a certain meaning in opposition to traditional or new ways of living in indigenous groups, as the AHDR I does, strengthens the dichotomy between indigenous and non-indigenous groups. This is obvious in the following quotation:

(t)oday, one might find among younger couples a situation where a mother holds a job outside the home while the husband is the homemaker with three or four children at home. ... These observations demonstrate that gender equality issues have to be understood from a uniquely Arctic perspective, different from the typical idea of power imbalance between males and females (Einarsson 2004, 189).

Men's changing roles in Arctic society and how they affect social problems are also highlighted. There is a devaluation of men's traditional roles, the welfare of men is jeopardised and at risk much more than that of women, and furthermore, modern development in the Arctic is in fact systematically disenfranchising Arctic men (Einarsson 2004, 191). This is said to be in contrast to the assumptions of feminist discourse on gender issues. This statement is problematic in several ways. Firstly, the poorer outcome for men compared to women in modern society is a highly focused issue. Secondly, the presumption is that women are the winners. Instead there might be groups of men who are gaining power and influence on the behalf 
of those men who are losing their foothold. Thirdly, men's social problems often have consequences for women. Men's violence against women does not decline when men are devalued.

A pattern of disproportionate out-migration by young women in combination with a higher rate of female marriage to outsiders plays a significant but under-studied role (Einarsson 2004, 192). Education seems to be one reason for women leaving the Arctic, but there is a complex of individual and structural push and pull factors. Many of the factors mentioned seem to be connected with a lack of influence and power to act. What kind of activities, jobs, educational possibilities, future scenarios are there in the region? Are these interesting enough for the women? It seems that women are better off if leaving the region than men.

One thing mentioned in the report is the relatively low representation of women in politics but also in the management of the natural resources and in emerging issues including climate change and contaminants (Einarsson 2004, 200). It is not that women are not interested; at the grassroots level women are prominent but they are less likely to attain decision-making positions. The discussion on the representative issue is a good example of moving beyond the gender roles of women and men. Here it is about the power and the influence of all citizens. I highlight this issue because of its importance for governance bodies within the region. I will return to some criticism from CEDAW Committee below.

There are several other issues raised in the report and one might have expected that the Arctic Council to take the report more thoroughly into account, but that did not happen.

The second Arctic Human Development Report (AHDR II) was published in 2015. The goal of this report was to provide an update to the first report, just over 10 years later, in terms of an assessment of the state of Arctic human development. The major trends and changes are unfolded, in order to identify policy relevant conclusions and key gaps in knowledge. The "new and emerging Arctic success stories" are also told. It is said to address critical issues and emerging challenges in Arctic living conditions, quality of life in the North, global change impacts and adaptation, and Indigenous livelihoods (Nordic Co-operation 2015).

A persistent knowledge gap can be noted in the report. Men and women, it is said, are not affected equally by climate change and globalisation, and their impacts on traditional and non-traditional economic activities in the Arctic, on political systems, on education and healthcare provision, etc. There is also a lack of knowledge about the gendered dimensions of contemporary cultural practices and expressions, including the (re)negotiation of cultural and other identities, the gendered dimensions of domestic violence, the gendered characteristics of decision-making 
regarding resources at different levels, the gendered nature of aging in the Arctic, the gendered experience of food and other (in)securities and the gendered nature of Arctic geopolitics (Nymand and Larsen 2015, 24, 493).

A comparison between the two reports regarding gender is made more difficult due to the fact that gendered dimensions are mainstreamed throughout the report (Nymand and Larsen 2015, 13). Mainstreaming gender accords with the globally accepted strategy for promoting gender equality adopted by UN in 1995 through the Beijing Declaration and Platform for Action. However, the strategy has its pros and cons, and there is a risk that gender mainstreaming can make gender equality invisible and prevent it being reflected on. In this case, not mainstreaming the 'gendered dimensions' could have facilitated a comparison between the situations in 2004 and in 2015.

However, searching for the problems raised by the first report in the second report shows that the situation has not changed in any significant degree. The same problems are still there and the lack of knowledge requiring more research is also pointed out in the second report but has not been met to any serious extent. It is striking that the statistics in the report, generally speaking, do not show the figures for men and women separately. The female out-migration, raised as a problem in AHDR 2004, is also highlighted in the second report (Nymand and Larsen 2015, 69). ${ }^{13}$ The reasons mentioned are the male-dominated labour market, women's wish to get an education and the permanence of women's migration. The relatively low representation of women in the governance of the region is still a problem (Nymand and Larsen 2015, chapter 5). There are still huge gaps in health status between indigenous and non-indigenous people in many parts of the region. The statistics in the report show the figures for different ethnic groups. There are gaps in the knowledge relating to 'violence in families'. Women and children, as well as the elderly, are pointed out as being particularly at risk (Nymand and Larsen 2015, 335). This is also confirmed by the CEDAW Committee, see below. The conclusion of the second report concerning gender issues is that much remains to be done.

The need for a system for tracking trends in human development in the Arctic was already noted in AHDR I. A set of indicators were identified in the first report, and in 2010 the Arctic Social Indicators (ASI-I) presented were; health and population, material wellbeing, education, cultural wellbeing, contact with nature, and fate control. Arctic Social Indicators II (ASI-II) is a follow-up activity to ASI-I (Nymand Larsen, Schweitzer and Petrov 2015). ASI-II contains five case studies. Gender imbalances and differences are also noted in this report, but the figures are not shown

\footnotetext{
${ }^{13}$ Figures concerning Greenland, also raised by Hamilton and Rasmussen (2010).
} 
separately for men and women. The report concludes with the argument that the long-term monitoring of human development in the Arctic would be greatly facilitated by the regular and frequent collection and reporting of relevant data, including those required for the proposed small set of ASI indicators (Nordic Co-operation, ASI II, 2015).

\section{The Barents Euro-Arctic Council (BEAC) and the Barents Regional Council (BRC)}

The BEAC seems explicitly to be more concerned with gender equality explicitly than the Arctic Council, 30 hits on 'gender equality' were found on the homepage of BEAC in 2014, 26 in 2015 (the same as 2014).

At the first meeting of Barents parliamentarians - the Barents Forum - in Kirkenes in 1997 and at the first conference in Alta in 1999 (both places in Norway) gender equality was already on the agenda together with transport, communications and social wellbeing (Barents Region, 2015). What was meant with gender equality is not specified.

On 14 November 2012 BRC adopted new Terms of Reference for cooperation within BEAC (Terms of Reference, 2012). The document summarises the existing practices and procedures and reiterates the principles of the co-operation, but it also introduces some novelties. The novelties are provisions concerning common values (Art 4) and gender equality (Art 5) as well as the role of youth (Art 6). Art 4 states that "(t)he Barents co-operation is founded on the values of respect for human dignity, freedom, democracy, equality, the rule of law, and respect for human rights, including the rights of persons belonging to minorities and physically challenged persons" (4.1), and "( $t$ )hese values are common to all the participating regions in a society in which pluralism, non-discrimination, tolerance, justice, solidarity, and equality between women and men prevail" (4.2). In addition, Art 5 states that "In line with the principles of the Barents co-operation, the participating regions will strive to ensure an equal gender representation when appointing their members of the RC and of the working groups."

In the introductory part of the joint communique from the XIII session in Kiruna, Sweden, 12 October 2011, the BEAC reaffirmed its strong commitment to improving the conditions for gender equality as a common democratic value (among others) in the Barents region. In the latest joint communique from the XIV Session in Tromsø, Norway, 29 October 2013, it is only said that gender equality is key to economic growth and prosperity. In earlier joint communiqués (the $9^{\text {th }}$ session 2003 in Umeå, Sweden, the 10th session in 2005 in Harstad, Norway, the $11^{\text {th }}$ session in 2007 in Rovaniemi, Finland and the XII session in 2009 in Murmansk, Russia) the 
Council also points to the importance of gender equality in the Barents Region, but not in the introductory part. The communique from 2003 (Art 25) calls for special efforts in close co-operation with the BEAC to safeguard gender equality and “...develop women's, including indigenous women's, employment opportunities, entrepreneurship and representation in political fora." 14

Gender equality in 2005, 2007 and 2009 is set in the section about Human and Social Development. The Council (in 2005) calls for efforts to safeguard gender equality and strengthen women's, including indigenous women's, employment opportunities, entrepreneurship and representation in political fora (Art 21). The Council (in 2007) highlights the importance of gender equality “.... and the strengthening of women's, including indigenous women's, employment opportunities, entrepreneurship and public representation." (Art 27). In the communiqué from 2007 the Council also calls for regular Barents Forums on Education and Research, working as platforms for education and research connected with other Barents activities and issues, such as gender issues (article 23). In 2009 (Art 12) the Council underlines the importance of ensuring gender equality and improving the situation of women, including indigenous women, with regard to employment opportunities, entrepreneurship, education and public representation.

It is interesting to compare the terms used for the ambitions regarding gender equality over the years. In 2003 and 2005 the Council calls for efforts to safeguard gender equality. In 2003 efforts is complemented by special. Was the mainstreaming strategy not yet acknowledged in 2003? In 2007, the Council highlights the importance of gender equality. The choices of words is different in 2009 and 2011, and it seems the ambition for activities that impact on living conditions is strengthened. In 2009, the importance of ensuring gender equality and of improving the situation of women are underlined by the Council. In 2011, the Council reaffirms its strong commitment to improve the conditions for gender equality. And, in 2013, the word conveying obligation on the part of the BEAC has disappeared totally.

\section{The Northern Dimension and EU Arctic Policy}

In the Policy Framework Document for the Northern Dimension it is stated that the Northern Dimension

(w)ill be based on the internationally recognized principles, such as good governance, transparency and participation, sustainable

\footnotetext{
${ }^{14}$ See for all the joint communiqués, BEAC Ministerial meetings (2015).
} 
development, gender equality, the rights of persons belonging to minorities, cultural diversity, social cohesion, fair working conditions and corporate social responsibility, non-discrimination, the protection of indigenous peoples and supports the further strengthening of civil society and democratic institutions (emphasis added), (Policy Framework Document 2015).

In the Political Declaration, nothing is said about gender equality (Political Declaration 2015).

The EU Arctic policy An integrated European Union policy for the Arctic (European Commission 2016) focuses on advancing international cooperation in responding to the impacts of climate change on the Arctic's fragile environment, and on promoting and contributing to sustainable development, particularly in the European part of the Arctic. The European commission expresses its will to engage with Arctic indigenous groups, but nothing is said about gender equality.

\section{The Council of the Baltic Sea States}

The Annual Forum of the EU Strategy for the Baltic Sea Region and the Baltic Development Forum Summit in Turku in 2014 had promotion of gender equality on the agenda (CBSS Events, 2015). "The work of the CBSS should reflect the principles of democracy, social inclusion, sustainability, cultural diversity and non-discrimination, including gender equality; and that these principles should be mainstreamed in all its work" (The Council of the Baltic Sea States, Priorities. 2015).

\section{The Nordic Council and the Nordic Council of Ministers}

There is a Nordic gender equality co-operation program within the general co-operation. The program for 2006-2012 said that the scope of the work to promote gender equality was quite broad (Focus on Gender - Working Toward an Equal Society 2006). The prioritisations in these years were gender and power, and gender and young people. The prioritisations mentioned in the programme for 2011-2014 were mainstreaming of the gender and equality perspective and active participation by men and boys (Gender Equality Creates Sustainable Societies 2011). In the current programme, running from 2015-2018, there are two overarching themes; the public sphere and welfare and innovation. In addition, there are two horizontal themes: sustainable development with a focus on diversity and participation by men and boys in gender-equality work. Gender mainstreaming is part of the strategy to implement the programme (Nordic Council of Ministers 2015). 
The Swedish Presidency of the Nordic Council of Ministers in 2013 focused on the prioritised action areas of gender equality in the labour market and gender equality in education (Sector programme Gender Equality 2013), while the Danish Presidency in 2015, prioritises the same things as in the general programme; the public sphere and welfare and innovation. More specifically, under welfare and innovation the sexually segregated educational choices and the differences between the sexes when it comes to moving to bigger cities are noted. Under the public sphere, four subthemes are identified; representation and democracy, sexualisation, antifeminism, and the media (Sektorprogram Likestilling 2015).

Interestingly, on the homepage of the Nordic Council and Nordic Council of Ministers news has been published of a call for a revision of the equality concepts. Equality should not only embrace gender but also disability, age, religion, sexual orientation and ethnicity. There is a risk, it is said, of political crisis if equality policy ignores diversity and only deals only with gender. (Warning: Equality must no longer be confined to gender 2013).

\section{The Saami Parliamentary Conference and Council}

Nothing is said about gender equality (Saami Council 2017).

\section{The practice of gender equality}

The doing of gender equality in the governance of the Arctic is concerned with gender equality put into practice. Is gender equality implemented, and if so how, in the governance of the region? Which activities have taken place? What is the outcome of such activities?

There have been very few activities directed to gender equality within the work of the Arctic Council. I have found three (!) such activities: a conference held in 2002, a project proposal for another conference planned for the autumn 2014, and the same conference that took place in October 2014. Moreover, the two reports on Arctic Human Development (AHDR I 2004 and ADHR II 2015) and the Arctic Social Indicator Reports (ASI-I 2010 and ASI-II 2015) can also be listed as activities, activities that themselves call for more activities on gender equality.

The conference held on 3-6 August 2002 in Saariselkä, Finland was entitled Taking wing - Conference on Gender equality and women in the Arctic. ${ }^{15}$ It was organised by the Gender Equality Unit at the Ministry of Social Affairs and Health in Finland, in co-operation with the Arctic council and the Nordic Council of Ministers. The goals were to raise the awareness

\footnotetext{
${ }^{15}$ Noticeable is that information about the conference seems to have been published on the website in July 2012, 10 years after the conference.
} 
of decision-makers about the situation of women in the arctic, and to act as a vehicle for getting actions supporting gender equality onto the agendas of the relevant existing bodies in the Arctic (the Arctic Council, Nordic Council, Nordic Council of Ministers, national and regional authorities and local and indigenous governments and indigenous peoples' organisations).

The conference was divided into three themes, Women and work, Gender in the Self Determination of Indigenous Peoples, and Violence against women. The first theme embraced women as entrepreneurs, use of land and land rights as well as living conditions. The second theme included leadership in the communities and in legislative practices. The last theme also included health issues, trafficking in women and prostitution.

During the Icelandic chairmanship, the Arctic Council, in collaboration with other bodies such as the United Nations Development Program, published the ADHR I in 2004. The report addressed critical issues including men's changing roles in society and how this affects social problems; women's security, job opportunities and out-migration; and women's positions of leadership and representation in decision-making bodies. A second Arctic Human Development Report was published in 2015 (ADHR II). The Stefansson Arctic Institute in Akureyri, Iceland was responsible for the reports.

During the first meeting of the Arctic Council Senior Arctic Officials under Canada's Arctic Council chairmanship in Whitehorse, Yukon on October 21 to 23, 2013, a project proposal entitled: Gender Equality in the Arctic: Current Realities and Future Challenges, was considered and granted funding. The project's objective was to

(p)romote extensive, policy-relevant dialogue on gender equality issues in the Arctic region in the context of current realities in terms of economic and social development as well as current and future challenges, inter alia relating to climatic and environmental changes (Whitehorse 2013).

A conference that gathered government representatives, policy makers, academics and a wide range of other stakeholders such as people from the business community, resource managers and users, community leaders and NGO representatives, was planned for the autumn of 2014, in order to facilitate and strengthen this dialogue. The main focus was thought to be on the diverse and differential situations of women and men throughout the circumpolar North and how to meet these societal challenges in the region. The conference, together with a comprehensive follow-up report, was expected to lay the foundation for a co-operation network including the various stakeholders researching, teaching and discussing and promoting gender equality issues in the Arctic. 
The conference held in October 2014 in Akureyri, Iceland 'Gender Equality in the Arctic: Current Realities and Future Challenges', according to the SWDG, laid the foundation for a formal co-operation network of stakeholders focused on gender equality in the Arctic. The conference brought together government, policy-makers, academics, business, community members, non-governmental organisations and others to address key issues in gender equity including access to and control over resources and political participation. The presentations at the conference were made available on the webpage of the conference (Gender Equality in the Arctic 2014), and a report was published (Gender Equality in the Arctic 2015).

The proposal to the latest conference was probably initiated during a public seminar event closely connected to the Arctic Council meeting in Kiruna in May 2013. The background for the initiative is a story that can only be told by those who participated in the process. During Sweden's chairmanship, in June 2012, I approached the Swedish chair and asked about their statement that "Sweden highlights the human dimension and the gender perspective in the Arctic Council." The reply was that there had been no activities had been made and no plans had (yet) been made. During the rest of the year 2012 we were in contact several times and finally in January 2013 a first conversation appeared in a panel discussion in relation to the Minister meeting in Kiruna in May 2013, the day before the last day of Sweden's chairmanship. A seminar day was arranged and as the final activity a panel discussion was held on gender equality in the Arctic. During that discussion, a proposal for a conference was made; the conference that was to take place in October 2014.

This story is interesting because it shows the prioritisation given to the gender issue within the work of the Arctic Council. I would not say that there is no interest, but it is not an exaggeration to say that gender equality is not a prioritised question.

The outcome of the commitments of the other bodies, such as the BEAC and BRC, two bodies that have been more explicitly outspoken on gender equality on the webpages, also seems to be very humble. Gender equality has been on the agenda twice (1997 and 1999). The more specific outcomes of those agenda items do not appear on the homepage.

According to an instruction for a project description it seems to be an advantage if the organisation of the project has a gender equality factor and that this appears in the description (International Barents Secretariat 2015). 


\section{The outcome of gender equality in the regional governance reflected through CEDAW state reports}

The rhetoric and the practice of gender equality within the regional bodies is studied under the presumption that the powers behind the bodies are states (or parts of states) that have political and legal obligations to achieve gender equality. When acting in bodies (established by the same States) they still have to fulfil the obligations. If regional bodies co-operate with private or semi-private stakeholders the accountability of the public bodies remains. Even if private corporations take social responsibility (framed as Corporate Social Responsibility) it is still the democratic institutions that bear the responsibility towards all their citizens and, also, have the (legitimate) power to act.

This is the background to why the CEDAW Committee's comments on some of the arctic states are used here as a mirror for what has been presented above, the rhetoric and the practice of gender equality within the regional governance of the Arctic. The comments are directed to the state parties which have within their territories and jurisdiction have the Arctic and the task of governing the Arctic.

All of the arctic states have ratified the CEDAW except the USA. Ratifying the Convention means that the state party is obliged to report to the CEDAW Committee every four years. However, it seems quite common to report less often. Two reports following on each other are not seldom combined and submitted at the same time. In addition to the state reports there are shadow reports from women's organisations and women's lobbies. These shadow reports have a certain impact on the CEDAW Committee's response to the state report, The CEDAW Committee considers the report at its meetings and responds to it. In the responses the Committee addresses both positive and negative points. The comments to different states vary and relate to the specific conditions in each state. Here I will give three examples, Sweden, Canada and The Russian Federation. I have chosen these three countries from among the eight arctic states because of their expected variations regarding conditions and the level of gender equality achieved. The other Nordic countries are considered to be comparable to Sweden and the USA has not ratified the CEDAW.

\section{Sweden}

The Swedish combined sixth and seventh periodic reports were submitted in 2006. The state party was requested to respond, in the next report, to the concerns expressed in the concluding observations on the reports from 
2006 given by the Committee in January $2008 .{ }^{16}$ Some of the concerns of the Committee regarding the 2006 report and relevant in this context are presented below (CEDAW/C/SWE/CO/7, 8 April 2008).

It is striking that Sweden with its self-image as one of the most gender equal countries in the world has a constitution that is gender-blind (this has also been pointed out in a government report on the constitution, SOU 2007:67). Also, the concept of equality is not in line with the constitution (paragraph 14). In relation to this comment the Committee calls for the CEDAW to be incorporated into domestic law, including the concept of substantive equality. Such an act could also enforce the obligations regarding Sweden's governance of the Arctic. This can be considered, together with the comment from the Committee on the lack of effectiveness in monitoring and accountability mechanisms, including sanctions for noncompliance, for gender mainstreaming at the municipal, regional and governmental level (paragraphs 20-21). The lack of effectiveness is not on the rhetorical level but on the practice level, in the same way as described above in the sections on public governance of the Arctic region.

The comment and drive for improvements when it comes to women in top management positions and on the boards of private companies (paragraphs 24-25) are relevant to the governance of the Arctic, because of the focus on natural resource management and business development. Women and men participate to almost the same extent in political representation, but when it comes to private companies and sectors relevant to the Arctic, especially in the field of natural resources and transportation, women "shine in their absence". This should make the governing bodies adopt an active strategy with such measures as quotas (suggested by CEDAW) to improve the number of women in high-ranking positions in the region. Gender segregation on the labour market is also relevant in this context. The Committee urged Sweden to take proactive concrete measures to eliminate occupational segregation (paragraph 27), a segregation that is pointed out in the AHDR report as also being problematic in the Arctic.

Saami women continue to suffer from discrimination within their communities and in society at large, and the CEDAW Committee urged Sweden to intensify its efforts to eliminate such discrimination (paragraphs 38-39). The kind of discrimination the Saami women experience is not described, but the statement can be analysed with help from the statements in the AHDR. There seems to be a presumption that indigenous women

\footnotetext{
${ }^{16}$ After this study was finished, the eighth and ninth reports were delivered in November 2014, and the Committee expressed its concern in the concluding observations CEDAW/C/SWE/CO/8-9 in March 2016. Unfortunately, nothing much has been changed to the better. One of the issues mentioned here, that has been changed, is the gender-blind character of the constitution. The language of the constitution has been changed to gender-neutral in 2011. Still, the concept of substantive equality has not been introduced.
} 
suffer from double discrimination, both within their communities and in society at large, in contrast to non-indigenous women. Constructing a contrast in this way between different groups of women can be questioned and understood as a stigmatisation of indigenous women.

Finally, regular and comprehensive studies on discrimination against indigenous women are also required. This fits in well together with the AHDR recommendations.

To sum up, using the comments of the CEDAW Committee as a tool with which to analyse Swedish participation in the regional governance of the Arctic could provide the governing bodies with valuable insights and could also form the basis for more proactive strategies.

\section{Canada}

Canada submitted the combined sixth and seventh periodic reports not long after Sweden (CEDAW/C/CAN/CO/7) ${ }^{17}$ The state party is requested to respond to the concerns expressed in the concluding observations on the sixth and seventh report given by the Committee in November 2008 in the next report. Some of the concerns of the Committee regarding the report and relevant in this context are presented below.

One of the Committee's main concerns is a presumed unwillingness to act on the part of the Federal Government and the lack of an efficient mechanism to ensure that the provincial and territorial governments establish legal and other measures to fully implement the Convention in a coherent and consistent manner. The unwillingness was also pointed out in the comment in the previous report (2003). The Committee urged the state to use its leadership and funding powers to set standards and establish an effective mechanism to implement the Convention at all levels of government. This reiteration of the urge reveals the Committee's disapproval (paragraph 12).

As expressed by the Committee; if the Convention is not fully implemented in the lower levels of government, the resistance can of course also characterise the governance of the Arctic. Combined with the fact that social assistance funds are at the discretion of the provinces and territories and there is no federal accountability mechanism to ensure minimum standards across the country, the Committee is concerned that there may have discriminatory effects (paragraphs 13-14). There have also been cuts in many social assistance schemes, with consequences for women who rely on social assistance for an adequate standard of living. Aboriginal women are one group that suffers from these cuts. The establishing of minimum

\footnotetext{
${ }^{17}$ The most recent reports, the eighth and ninth CEDAW/C/CAN/CO/8-9, were delivered in late 2014 and the concluding observation by the Committee was adopted 25 November 2016.
} 
standards applicable at the federal, provincial and territorial levels, is called for. The AHDR states that many residents in the Arctic would not receive outstanding Human Development Index (HDI) scores. Yet, many of those residents, among them many indigenous people, would not think of themselves as lagging behind (AHDR p. 16). A good life can be achieved without a high material standard. However, when the CEDAW talks about women relying on social assistance in order to survive it moves beyond the question of a good or bad life. Poverty among women is also pointed out as a problem (paragraphs 39-40).

The problem with formally discriminatory legislation is a problem that is unknown in the Swedish context, a context in which substantive equality but not formal equality is lacking (paragraphs 17-20). In Canada, the Indian Act continues to discriminate against, for example, descendants of Indian women married to non-Indian men and descendants of Indian men married to non-Indian women with their respect to their equal right to transmit Indian status to their children and grandchildren. It is a matter of urgency to eliminate this and other discriminatory provisions.

Employment of women and their participation in public life should also be promoted according to the Committee (paragraphs 23-24, and 35-36). This impacts on the governance of the Arctic. Both women and men are important as participants in the shaping of society. One of the worst things pointed out by the Committee is the many cases of missing and murdered aboriginal women neither being neither fully investigated nor attracting priority attention (paragraphs 31-32). Presumed racialised patterns should be investigated. Concerning the governance of the Arctic, it is of course urgent to take this into account, governance is about constructing good conditions for all citizens and, not the least, any business development requires an infrastructure that supplies the industry with labour, labour that is healthy and does not get murdered.

Aboriginal women suffer from multiple discrimination (paragraph 43). In contrast to the comments in the Swedish report, The Committee spelled out the kind of discrimination, namely access to employment, housing, education and healthcare. The Committee encouraged the state party to eliminate de jure and de facto discrimination against aboriginal women (and other groups of women), both in society at large and in their communities.

To sum up, the situation in Canada is not completely different from that in Sweden but there seems to be more formally discriminatory legislation remaining, bigger differences between various groups of women and the same kind of problems (maybe to a different degree) with a lack of women in high positions in the society. 


\section{Russian Federation}

The sixth and seventh periodic report from the Russian Federation was considered by the CEDAW Committee in August 2010 (CEDAW/C/USR/CO/7). The Committee started its response by reiterating the obligation of the state party to systematically and continuously implement the Convention. Even if the Government has the full responsibility for the complete implementation of the obligations of the Convention, the Committee stresses that the Convention is binding on all branches of the government (paragraphs 8-11). The criticism here indicates the risk of a lack of awareness of the Convention also when it comes to the governance of the Arctic. In addition, the institution for complaints about discrimination, the Ombudsman of the Russian Federation, has not received any complaint from women concerning discrimination. This may indicate that the state party does not have a comprehensive or effective (paragraphs 16-17) legal complaint system for women, according to the Committee.

Neither the constitution, nor other appropriate legislation, contains a definition of discrimination or expressly prohibits discrimination on the grounds of sex (paragraph 12). There is, at this time (2010), a draft federal law on gender equality but no adopted law. The Committee is seriously concerned and urges the enactment of such a law. Awareness about the Convention seems to be low in the Russian Federation, and the Committee therefore urges the state party to ensure a sufficiently knowledge about it and its optional protocol (paragraphs 14-15).

Women are not equally represented in all spheres of life and stereotypes of women seem to be a hindrance (paragraphs 18-21). The state party should establish an effective national machinery for the advancement of women, in political and public life (paragraphs 30-31), as well as a strategy for eliminating traditional practices and stereotypes that discriminate against women. The stereotypes are linked to a patriarchal structure, which in turn is linked to the problem of men's violence against women. The infrastructure for protecting women is not well developed, especially outside the larger cities (paragraphs 22-23). Nothing is said about indigenous women in particular; instead women in some specific areas are pointed out as being more exposed to violence (paragraphs 24-25). The situation of rural women (paragraphs 42-43) and ethnic minority women (paragraphs 44-45) is problematic and the Committee asked for measures to improve the situation and to eliminate multiple discrimination (paragraphs 46-47). The high and increasing prevalence of trafficking and prostitution was pointed out (paragraphs 26,28 ).

The recommendation for the next report (expected to be delivered in 2014) was to include women's NGOs in the process. The recommendation added the image of the Russian Federation, presented in the statement of 
the Committee, as a society in which women are in general subordinated and in which a patriarchal structure is very dominant.

\section{Conclusion: Taking gender equality seriously?}

Governance in the Arctic, according to a statement in the ADHR II, pushes the edges of governance innovation (Nymand Larsen and Findahl 2015, 185). This is certainly not true about governance in relation to gender equality. On the contrary, gender equality seems to be almost absent in the rhetoric, the activities and in the outcomes of the governance, or, if present, mostly as statements about lack of knowledge or figures without any in-depth analyses and strategies for what could be done. There is a serious lack of systemic knowledge about gender realities and needs that should be addressed (also pointed at in Nord 2016b, 84). The conclusion is, unfortunately, that the Arctic governance bodies have, so far, not given their attention to any greater extent to gender equality and the impacts of economics, policies and governance on women, despite the fact that it is legitimate to have expectations of such measures. Governance in the Arctic is not "taking gender equality seriously"18.

The living conditions in the Arctic and the situation of the governance of the Arctic are not gender equal. Women are at a systemic disadvantage in terms of the representation of men and women, meeting the needs of all citizens, or building a society that promotes gender equality. Therefore, the need to take gender equality seriously is quite evident. What is lacking is domestic, regional, and, even global lack of political awareness or will to focus on women in Arctic and northern regions. It is also clear that Indigenous peoples' interests remain secondary to other interests, even when compared with concerns regarding women as a general class.

The study of how gender equality is expressed, how gender equality is practiced within the governance, and the considerations of the CEDAW Committee, shows that there is a lack of awareness and an absence of activities that could meet the needs of all citizens in the Arctic. It also shows, even though this has not been the main focus in the chapter, that indigenous people's interests are secondary to other interests. How can the lack of interest be explained?

One aspect to start with is the purpose of the governance of the Arctic. The governance is based on conflicting interests, the interest in access to natural resources and trade, the interest in protecting the environment, the interest in balance between the majority population and the indigenous

\footnotetext{
${ }^{18}$ The title of a United Nations Development Programme in 2006 with the objective to help nations to build democratic governance and to fulfil the Millenium Development Goals, especially the third "to promote gender equality and empower women”, Taking Gender Equality Seriously (2006).
} 
populations which often depend on nature for survival (in several respects) in a more direct way. Governance of the Arctic is, or should be, the democratic response to and balancing of conflicting interests, but one problem is that the governing bodies also have economic interests in the Arctic and/or are impregnated by an economic rationality. The interest of exploitation of natural resources seems to be the most influential and the other interests are perceived as something we must protect from the inevitable development. The conclusion is that the governance mechanisms of the Arctic are based on an economic rationality rather than on a gender equal and human rights rationality, despite far-reaching obligations to mainstream gender equality in every activity and to promote the human rights of indigenous people.

Whose interests and which interests are given priority in the balancing between conflicting interests can be understood through the way the governance is organised. The Arctic Council, for instance, has eight member states, with a rotating chairmanship. The chairman state will set the agenda for the term. All decisions are to be made by consensus. The indigenous people are represented as permanent participants, which means that they have full consultation rights in connection with the Council's negotiations and decisions. It is said that they make valuable contributions to the Council's activities in all areas. What is more, non-arctic states with interests in the Arctic (probably economic interests) have observer status. They have no influence formally, but they have access to information about the work of the Council and there is a risk that they may use that information for their own ends.

The organisation tells us about whose interests are maintained. It also tells us about which interests are given priority. The task for the working groups is to "react to the use" of the Arctic. Exploration of natural resources and increased access to trades impact on the environment and on people living in the area. Implicitly, this means that the exploration and use as such, is not an issue which can be questioned. It is self-evident that $W E$ (the member states majority population?) need to use the region, but when doing so WE have to be responsible and try to reduce the negative impact.

The governance, as a democratic institution, has (should have) the obligation to meet the needs of all. The question is whether the structure of the governance meets the needs of some more than others? Gender equality (as well as equality between different ethnic groups) is not prioritised in this governance. One might expect it to be because of the obligations of the states.

The importance of active states in promoting gender equality is obvious, but the states must have legitimacy and be able to govern powerfully, both with reference to the government and to other stakeholders. There seems 
to be a problem, or at least a risk, in states with a federal structure, such as Canada and the Russian Federation, that not all levels of the government will embrace the obligations in the Convention. The Committee calls upon the state party to use its leadership and funding power to set standards and establish effective mechanisms to ensure accountability and implementation of the Convention throughout its territory, at all levels in which government participates. The comments on Sweden are about the effectiveness of the mechanisms but not about the lack of leadership and funding powers.

The following final reflections are about gender equality and the importance of considering the meaning of gender equality. It is obvious that gender equality involves both rhetoric and practice. The experience of feminist scholars is that gender equality is more talked about than acted on. This study confirms that perception.

Another concern is the importance of both formal and substantive gender equality, and moreover, the connection with (general) equality. Formal gender equality is a necessary condition, but not sufficient, condition. Active measures are needed to achieve substantial gender equality. Such an achievement seems to be facilitated by a general of equality in society.

The last reflection concerns the importance of a critical examination of the conditions when it comes to issues of power and representation, as well as risks involved in being dependent on others for support (both individuals and state), lack of wellbeing and stereotypes, unequal structure of society and the problem with not being open to different perceptions of identity (what is male, what is female) or to different definitions of feminism. Persistent stereotypes and structures often seem to stigmatise women and indigenous groups, but also men. The focus must be on participation and active governance based on gender equality and human rights for indigenous people to construct a society for all, as well as on the responsibility that democratic institutions have to organise such participation and construction. 


\section{Acknowledgements}

All maps that appear in this article are used with permission. The author wants to thank Winfried Dallmann, Hanna-Elina Koivisto, Aino Lipsanen and Samiskt informationscentrum for their cooperation during this process.

\section{References}

Arctic Centre. 2015. http://www.arcticcentre.org/EN/SCIENCECOMMUNICATIONS/Arctic-region/Arctic-Indigenous-Peoples (Accessed 2015-07-03).

Arctic Council. 2015. http://www.arctic-council.org/index.php/en/ (Accessed 2015-07-03).

Arctic Council Observers. 2017. www.arcticcouncil.org/index.php/en/about-us/arctic-council/observers (Accessed 2017-02-08).

Arctic Forum Foundation. 2015. eu-arctic-forum.org/about-the-eu-arcticforum-in-the-european-parliament/origins/ (Accessed 2015-07-03).

Arctic portal. 2015. http://portlets.arcticportal.org/the-people (Accessed 2015-07-03)

Barents Euro-Arctic Council. 2015. http://www.beac.st/en (Accessed 201507-03).

Barents Euro-Arctic Council website. 2017. (www.beac.st/?DeptID=8604) (Accessed 2017-02-08).

Barentsnova. 2015. http://innovation.barentsnova.com/ (Accessed 2015-0703).

Barents Region. 2015. Co-operation and dialogue towards sustainable development, http://www.barentsinfo.fi/beac/docs/parliamentary_beac_info_eng.pdf (Accessed 2015-07-01).

BEAC Ministerial meetings. 2015. http://www.beac.st/en/Barents-EuroArctic-Council/Ministerial-meetings (Accessed 2015-07-01).

CBSS Events. 2015. http://www.cbss.org/one-thousand-baltic-sea-actorsgather-turku/ (Accessed 2015-07-01).

CEDAW/C/CAN/CO/7, 7 November 2008.

CEDAW/C/CAN/CO/8-9, 25 November 2016.

CEDAW/C/SWE/CO/7, 8 April 2008.

CEDAW/C/SWE/CO/8-9, 10 March 2016.

CEDAW/C/USR/CO/7, 30 July 2010.

Charter of Fundamental Rights of the European Union, European Union, 26 October 2012, 2012/C

326/02, http://www.refworld.org/docid/3ae6b3b70.html (Accessed 2017-02-13). 
Conference of parliamentarians of the Arctic region. 2015. http://www.arcticparl.org/ (Accessed 2015-07-03).

Declaration on the Establishment of the Arctic Council. 1996. http://www.arctic-council.org/index.php/en/about-us/arcticcouncil/history (Accessed 2015-07-03).

Economic and Social Council. 2014. Review and appraisal of the implementation of the Beijing Declaration and Platform for Action, E/CN.6/2015/3 (Dec 15, 2014).

Einarsson, Niels, Larsen, Joan Nymand, Nilsson, Annika and Young, Oran R. (eds.). 2004. Arctic Human Development Report (AHDR I). Akureyri: Stefansson Arctic Institute.

EU Arctic Policy. 2015. http://eeas.europa.eu/arctic_region/index_en.htm (Accessed 2015-07-03).

European Commission. 2016. An integrated European Union Policy for the Arctic.

http://eeas.europa.eu/archives/docs/arctic_region/docs/160427_jointcommunication-an-integrated-european-union-policy-for-thearctic_en.pdf (Accessed 2017-02-08).

Focus on Gender - Working Toward an Equal Society. 2006. Nordic Gender Equality Co-operation Programme 2006-2010. Nordisk Ministerråd.

Gender Equality Creates Sustainable Societies. 2011. Nordic co-operation on gender equality 2011-2014. Nordiska Ministerrådet.

Gender Equality in the Arctic. 2015. http://www.mfa.is/media/nordurslodir/Gender-Equality-in-theArctic.pdf (Accessed 2015-07-01).

Gender Equality in the Arctic. 2014. Current realities, future challenges. http://arcticiceland.is/en/gender-equality-in-the-arctic (Accessed 201507-01).

Geopolitics in the High North. 2017. http://www.geopoliticsnorth.org/ (Accessed 2017-02-08).

Hamilton, Lawrence C. and Rasmussen, Rasmos Ole. 2010. Population, sex ratios and development in Greenland. Arctic, 63 (1): 43-52.

International Barents Secretariat. 2015. Tips for Your Project Description. www.barentsinfo.fi/beac/docs/Tipsforprojectdescription.docx (Accessed 2015-07-01).

Kent, Neil. 2014. The Sami Peoples of the North: A Social and Cultural History. London: C Hurst Co Publishers Ltd.

Keskitalo, Eva Carina Helena. 2004. Negotiating the Arctic: The Construction of an International Region. New York and London: Routledge.

Lahey, Kathleen A. 2010. Women, Substantive Equality, and Fiscal Policy: Gender-Based Analysis of Taxes Benefits, and Budgets. Canadian Journal of Women and the Law 22 (1): 27-106. 
New Scientist. 2015. www.newscientist.com/article/dn23553-china-gainsobserver-status-on-the-arctic-council.html\#.Uvo7SCRwDWo (Accessed 2015-07-01).

Nord, Douglas C. 2016a. The Changing Arctic: Creating a Framework for Consensus Building and Governance within the Arctic Council. Hampshire and New York: Palgrave Macmillan.

Nord, Douglas C. 2016b. The Arctic Council: Governance within the Far North. London and New York: Routledge.

Norden. 2015. http://www.norden.org/en (Accessed 2015-07-03).

Norden, Sustainable Development. 2015. http://www.norden.org/en/nordic-council-of-ministers/ministers-for-cooperation-mr-sam/sustainable-development/indicators-for-sustainabledevelopment-1/the-nordic-welfare-model/ (Accessed 2015-07-03).

Nordic Co-operation. 2015. http://norden.divaportal.org/smash/record.jsf?pid=diva2\%3A788965\&dswid=-5388 (Accessed 2015-07-01).

Nordic Co-operation, ASI II. 2015. http://norden.divaportal.org/smash/record.jsf?pid=diva2\%3A789051\&dswid=3428 (Accessed 2015-07-01).

Nordic Welfare. 2015. http://nordicN.org/Ovrigt/About-us/ (Accessed 201507-03).

Nordregio. 2017a. Population change in the Arctic and neighboring regions (2000-2010).

http://www.nordregio.se/Templates/NordRegio/Pages/MapPage.aspx?id $=738 \&$ epslanguage $=$ en (Accessed 2017-02-13).

Nordregio. 2017b. Female and male in 2012.

http://www.nordregio.se/Templates/NordRegio/Pages/MapPage.aspx?id $=2323 \&$ epslanguage $=$ en (Accessed 2017-02-13).

Northern Dimension. 2015. http://www.northerndimension.info/ (Accessed 2015-07-03).

Northern Dimension EU. 2015. http://www.eeas.europa.eu/north_dim/ (Accessed 2015-07-03).

Nymand Larsen, Joan and Findahl, Gail (eds.). 2015. Arctic Human Development Report: Regional Processes and Global Linkages (AHDR II). Copenhagen: Nordisk Ministerråd.

Nymand Larsen, Joan, Schweitzer Peter and Petrov, Andrey (eds.). 2015. Arctic Social Indicators ASI II: Implementation. Copenhagen: Nordisk Ministerråd.

On an Arctic Policy for the EU. 2015. http://europa.eu/rapid/pressrelease_CES-13-7_en.htm (Accessed 2015-07-03).

Philipps, Lisa. 2006. Gender Budgets and Tax Policy-making: Contrasting Canadian and Australian Experiences. Law in Context 24 (2): 143-168. 
Policy Framework Document. 2015.

http://eeas.europa.eu/north_dim/docs/nd_framework_document_2006_e n.pdf, 3 (Accessed 2015-07-01).

Political Declaration. 2015. http://www.enpiinfo.eu/library/content/political-declaration-northern-dimension-policy (Accessed 2015-07-01).

Saami Council. 2017. www.saamicouncil.net/en (Accessed 2017-02-08).

Samiskt informationscentrum. 2017. Sametinget, http://www.samer.se/2167 (Accessed 2017-02-08).

Sector programme Gender Equality. 2013. Swedish Presidency. Nordic Council of Ministers.

Sektorprogram Likestilling. 2015. http://norden.divaportal.org/smash/get/diva2:768658/FULLTEXT01.pdf (Accessed 2015-0701).

Siva. 2015. http://sivaim.no/home/ (Accessed 2015-07-03).

SOU series 2007:67, Regeringsformen ur ett könsperspektiv [Swedish Official Report (SOU) 2015:55, The Instrument of Government in a Gender Perspective] (Swed.).

Sweden's strategy for the Arctic region. 2011. Government Offices of Sweden, Ministry for Foreign Affairs. http://www.government.se/contentassets/85de9103bbbe4373b55eddd7f 71608da/swedens-strategy-for-the-arctic-region (Accessed 2017-02-08).

Söderbaum, Fredrik. 2004. Modes of Regional Governance in Africa. Global Governance 10 (4): 419-436.

Taking Gender Equality Seriously. 2006.

http://www.undp.org/content/dam/aplaws/publication/en/publications/ womens-empowerment/taking-gender-equality-seriously2006/TakingGenderEqualitySeriously.pdf (Accessed 2017-02-08).

Terms of Reference. 2012. https://www.barentsinfo.fi/beac/docs/RegioanCouncil-Terms-of-Reference-2012.pdf.pdf (Accessed 2017-02-13).

The Arctic governance project. 2015. http://arcticgovernance.custompublish.com/governance.4632456142145.html (Accessed 2015-07-03).

The Council of the Baltic Sea States. 2015. http://www.cbss.org/council/ (Accessed 2015-07-03).

The Council of the Baltic Sea States, Priorities. 2015. http://www.cbss.org/cbss-long-term-priorities/ (Accessed 2015-07-01). The Treaty on the Functioning of the European Union (TFEU) (no date). The Treaty on European Union (TEU) (no date). 
The World Bank. 2006. Governance \& Gender Equality, Gender and Development Group, April 2006, http://www.capwip.org/readingroom/TopotheShelf.Newsfeeds/2006/Go vernance and Gender Equality \%282006\%29.pdf (Accessed 2017-02-08).

Nordic Council of Ministers. 2015. Together for Gender Equality - a Stronger Nordic Region. Nordic co-operation programme on gender equality 20152018.

United Nations. 1995. Report of the Fourth World Conference on Women (1995).

United Nations. 2007. Declaration on the Rights of Indigenous Peoples, General Assembly resolution 61/295 (Sep 13, 2007).

United Nations. 2015. Transforming our world: the 2030 Agenda for Sustainable Development, General Assembly resolution 70/1 (Oct 21, 2015).

Warning: Equality must no longer be confined to gender. 2013.

http://www.norden.org/en/news-and-events/news/warning-equality-

must-no-longer-be-confined-to-

gender/?searchterm=revision\%20of\%20the\%20equality\%20concept

(Accessed 2017-02-13).

Whitehorse. 2013. ACSAO-CA01 Doc. 6.7.3 Oct 2013, https://oaarchive.arctic-

council.org/bitstream/handle/11374/1280/SAO_Whitehorse_Oct2013_FINA

LReport_8_January_2014.pdf?sequence=1 (Accessed 2017-02-01).

\section{Notes on contributor}

Eva-Maria Svensson, LLD, Professor of Law at the Department of Law, School of Business, Economics and Law, University of Gothenburg, Sweden. She is also Director for Centre for Interdisciplinary Gender Research (GIG) at the same university. Svensson's research focuses mainly on legal philosophy and theory, in particular within the field of feminist/gender legal studies. Other research areas are freedom of expression and ageing studies in law. 